Ludmila Grechi Fim

\title{
ESTUDO DO CRESCIMENTO CELULAR EM CULTURAS \\ EMBRIOGÊNICAS E NÃO-EMBRIOGÊNICAS \\ DE CANA-DE-AÇÚCAR
}

Dissertação apresentada ao Programa de Pós-Graduação Interunidades em Biotecnologia USP/Instituto Butantã/IPT, para obtenção do Título de Mestre em Biotecnologia. 
Ludmila Grechi Fim

\section{ESTUDO DO CRESCIMENTO CELULAR EM CULTURAS \\ EMBRIOGÊNICAS E NÃO-EMBRIOGÊNICAS \\ DE CANA-DE-AÇÚCAR}

Dissertação apresentada ao Programa de Pós-Graduação Interunidades em Biotecnologia USP/Instituto Butantã/IPT, para obtenção do Título de Mestre em Biotecnologia

Área de Concentração: Biotecnologia

Orientador: Prof. Dr. Vanildo Silveira

Co-Orientadora: Prof $^{\mathrm{a}}$. $\mathrm{Dr}^{\mathrm{a}}$. Eny lochevet Segal Floh

Versão original

\section{São Paulo}




\section{DADOS DE CATALOGAÇÃO NA PUBLICAÇÃO (CIP) \\ Serviço de Biblioteca e Informação Biomédica do Instituto de Ciências Biomédicas da Universidade de São Paulo}

reprodução não autorizada pelo autor

Fim, Ludmila Grechi.

Estudo do crescimento celular em culturas embriogênicas e nãoembriogênicas de cana-de-açúcar / Ludmila Grechi Fim. -- São Paulo, 2012.

Dissertação (Mestrado) - Universidade de São Paulo. Instituto de Ciências Biomédicas. Programa de Pós-graduação Interunidades em Biotecnologia USP/IPT/Instituto Butantan. Área de concentração: Biotecnologia. Linha de Pesquisa: Fisiologia vegetal.

Versão do título para inglês: Study of cell growth in embryogenic and non-embryogenic cultures of sugarcane.

Descritores: 1. Cana-de-açúcar 2. Proteínas 3. Carboidratos 4. Amido 5. Poliaminas 6 Cultura de tecidos vegetais I. Silveira, Prof. Dr. Vanildo II Universidade de São Paulo. Instituto de Ciências Biomédicas. Programa de Pós-graduação Interunidades em Biotecnologia USP/IPT/Instituto Butantan III.Título 
Candidato(a): $\quad$ Ludmila Grechi Fim.

Título da Dissertação: Estudo do crescimento celular em culturas embriogênicas e não-embriogênicas de cana-de-açúcar.

Orientador(a): $\quad$ Prof. Dr. Vanildo Silveira.

A Comissão Julgadora dos trabalhos de Defesa da Dissertação de Mestrado, em sessão pública realizada a .....................................,
( ) Aprovado(a)
( ) Reprovado(a)

Examinador(a): Assinatura:

Nome:

Instituição:

Examinador(a): Assinatura:

Nome:

Instituição:

Presidente: Assinatura:

Nome:

Instituição: 


\section{AGRADECIMENTOS}

Agradeço ao meu orientador Prof. Dr. Vanildo Silveira, por me direcionar e apoiar no desenvolvimento deste projeto e pela amizade.

À Prof ${ }^{a}$. Eny I. S. Floh, por me acolher no Laboratório de Biologia Celular de Plantas (BIOCEL, Depto. Botânica, IB/USP) e por contribuir com o desenvolvimento de meu trabalho.

Aos meus pais, Valmir e Ivete, por me proporcionarem o desenvolvimento pessoal adequado, me permitindo alcançar o desenvolvimento profissional que almejei. Por me amarem em qualquer circunstância.

À minha linda Lívia, meu amor, por entender minha ausência em tantos momentos importantes.

Ao meu noivo Douglas, pela cumplicidade, por me apoiar em todas as decisões, me ouvir e compreender, mesmo nos momentos em que a distância tanto atrapalhava.

À amiga Keitty que, mais uma vez esteve por perto e me socorreu todas as vezes que precisei.

À Amanda, por estar comigo em todos os momentos de dúvidas referentes aos procedimentos no BIOCEL e por se tornar uma grande amiga.

Ao BIOCEL, por disponibilizar aparelhos e reagentes necessários para desenvolvimento desta pesquisa e aos companheiros de laboratório, Carmem, Fernanda, Leonardo e Prof. André, pela colaboração.

Ao Laboratório de Biotecnologia (LBT/CBB/UENF), por manter parceria conosco e disponibilizar suas dependências para desenvolver boa parte do meu projeto, e a todos os companheiros de laboratório, especialmente a Tatiana, pela ajuda e amizade de sempre.

À Universidade de São Paulo por me proporcionar um excelente conhecimento científico e acadêmico, de forma gratuita.

À CAPES, pela concessão da bolsa de mestrado. 
Às agencias de fomento CNPq, FAPESP e FAPERJ, pelo aporte financeiro dado ao nosso grupo de pesquisa.

E finalmente a Deus e a Nossa Senhora que, acima de tudo, estão sempre à minha frente, me trazendo coragem e determinação para alcançar a realização dos objetivos que traço em minha vida. 


\section{RESUMO}

Fim, LG. Estudo do crescimento celular em culturas embriogênicas e nãoembriogênicas de cana-de-açúcar. [dissertação(Mestrado em Biotecnologia)] São Paulo: Instituto de Ciências Biomédicas, Universidade de São Paulo, 2012.

A cana-de-açúcar é uma das culturas com maior importância econômica mundial, sendo responsável por aproximadamente $70 \%$ do açúcar produzido, além de ser uma fonte cada vez mais importante de biocombustível. O Brasil é, na atualidade, o maior produtor e exportador mundial de açúcar e álcool derivados de cana-deaçúcar, sendo São Paulo o Estado de maior produção nacional. Devido ao seu destaque global, atualmente muitos estudos têm sido direcionados para gerar melhorias na cana-de-açúcar, principalmente por meio de biotecnologias. A integração de técnicas biotecnológicas, como a cultura de tecidos e a engenharia genética tem proporcionado novas oportunidades para a produção de cultivares geneticamente superiores, com características desejadas. Das técnicas de cultura de tecidos, a embriogênese somática possui características atraentes, como a capacidade de produzir rapidamente um grande número de plantas e a formação de embriões somáticos de forma eficiente, regenerando plantas saudáveis e vigorosas. Neste contexto, esta pesquisa de mestrado teve como objetivo estudar aspectos bioquímicos da fase de multiplicação celular, que antecede a formação de embriões somáticos, com o intuito de adquirir conhecimentos sobre o desenvolvimento das células de cana-de-açúcar da variedade SP80-3280, para um melhor entendimento da embriogênese somática nessa espécie. Com esse intuito, culturas embriogênicas (CE) e não-embriogênicas (CNE) foram estabelecidas, subcultivadas e monitoradas. Foram analisados o crescimento celular e os perfis de carboidratos, de amido, de poliaminas e de proteínas totais. Com o estabelecimento das curvas de crescimento de CE e CNE, observamos que ambas as culturas tiveram o máximo de seu crescimento aos 24 dias de cultivo, momento em que iniciaram uma redução de sua matéria fresca (MF). O maior incremento em MF foi encontrado em CE. Na análise de carboidratos foi demonstrado que a sacarose é o carboidrato predominante em CE enquando que em CNE a glicose foi observada em maior quantidade. Em CE os conteúdos de frutose e glicose variam simultaneamente e obedecendo o mesmo padrão de variação, demonstrando a relação entre seus metabolismos. Com a quantificação de amido encontramos as maiores concentrações em CNE, o que pode demonstrar que CE utilizam a energia originada da degradação de amido para capacitar suas células a desenvolver a embriogênese somática. Já com a quantificação de proteínas totais observamos conteúdos significativamente maiores em CE, pois proteínas de reserva para desenvolvimento do embrião provavelmente estão sendo acumuladas. Por fim, a análise de poliaminas (PAs) livres mostrou maiores quantidade de PAs em CNE, sendo a espermina predominantes em CE, enquanto que em CNE a putrescina foi observada em maior concentração. Foi demonstrado um menor valor de razão entre PAs [Razão PA= Put/(Spd+Spm)] em $C E$, o que também se relaciona a sua capacidade de desenvolver a embriogênese somática.

Palavras-Chave: Cana-de-açúcar. Carboidratos. Amido. Proteínas. Poliaminas. 


\begin{abstract}
Fim, LG. Study of cell growth in embryogenic and non-embryogenic cultures of sugarcane. [Master's thesis (Biotechnology)] São Paulo: Instituto de Ciências Biomédicas, Universidade de São Paulo, 2012.

The sugarcane is one of the most economically important crops of the world, accounting for approximately $70 \%$ of sugar produced, in addition to being an increasingly important source of biofuel. Brazil is currently the largest producer and exporter of sugar and ethanol derived from sugarcane, and the State of São Paulo contributes with the greatest share. Due to the global importance, many studies are directed to improve sugarcane production, mainly through biotechnology. The integration of biotechnology techniques, such as tissue culture and genetic engineering has provided new opportunities for the production of genetically superior cultivars with desired traits. Tissue culture and somatic embryogenesis techniques have attractive features, like the ability to quickly produce a large number of plants and the efficient formation of somatic embryos, affording to regenerate healthy and vigorous plants. In this context, this master's research investigates biochemical aspects of cell multiplication phase, which precedes the formation of somatic embryos in order to gain knowledge of the development of cells of sugarcane variety SP80-3280, towards a better understanding of somatic embryogenesis in this species. To that end, embryogenic cultures (CE) and non-embryogenic cultures (CNE) were established, subcultured and monitored. Their cell and developmental profiles of carbohydrates, starch, polyamines and total protein were analyzed. Using growth curves of CE and CNE, we observed that both cultures reached maximum growth on the 24th day of cultivation, at which time fresh weight (FW) started to decrease. The largest increase in FW was found in CE. With the quantification of fructose, glucose and sucrose, it was demonstrated that the predominant carbohydrate is sucrose in CE and in CNE is glucose. Additionally, it was also observed that contents of fructose and glucose in CE vary simultaneously, demonstrating the relationship between their metabolisms. Quantification of starch revealed the highest concentration in CNE, which demonstrates that CE uses energy derived from starch degradation to enable its cells to develop somatic embryogenesis. However, the quantification of total protein content was significantly higher in CE, as storage proteins for development of the embryo are probably being accumulated. Finally, free polyamines contents were higher in CNE, the predominant PA in CE being spermidine and in CNE putrescine, which relates to the type of development of cells of each culture. Furthermore, we demonstrated a lower PAs ratio [Ratio PA $=$ Put $/(\mathrm{Spd}+\mathrm{Spm})$ ] in $\mathrm{CE}$, which also relates to its ability to develop somatic embryogenesis.
\end{abstract}

Keywords: Sugarcane. Carbohydrates. Starch. Proteins. Polyamines. 


\section{LISTA DE FIGURAS E TABELA}

Figura 1 - Modulação da embriogênese somática

Figura 2 - Via metabólica de poliaminas

Figura 3 - Esquema da obtenção dos explantes em cultivares de cana-de-açúcar

Figura 4 - Curvas de Crescimento de CE e CNE 37

Figura 5 - Perfil de Frutose durante a multiplicação celular 38

Figura 6 - Perfil de Glicose durante a multiplicação celular 39

Figura 7 - Perfil de Sacarose durante a multiplicação celular 40

Figura 8 - Perfil de Amido durante a multiplicação celular 42

Figura 9 - Perfil de Proteínas Totais durante a multiplicação celular 43

Figura 10 - Perfil de Putrescina durante a multiplicação celular 44

Figura 11 - Perfil de Espermidina durante a multiplicação celular 45

Figura 12 - Perfil de Espermina durante a multiplicação celular 46

Figura 13 - Perfil de Poliaminas Totais durante a multiplicação celular 48

Figura 14 - Razão entre Poliaminas durante a multiplicação celular 49

Tabela 1 - Quantidades médias dos parâmetros bioquímicos analisados 49 


\section{LISTA DE ABREVEATURAS E SIGLAS}

2,4-D - Ácido 2,4-Diclorofenoxiacético

ABA - Ácido Abscísico

BOD - Câmara de Germinação

CE - Culturas Embriogênicas

CNE - Culturas Não-Embriogênicas

CONAB - "Companhia Nacional de Abastecimento"

CV - Coeficiente de Variação

DAH - 1,7-diaminoheptano

DTT - Dithiothreitol

ELSD-LT II - Detector de Espalhamento de Luz

$\mathrm{EtOH}-$ Etanol

HPLC - Cromatografia Líquida de Alta Eficiência

IAA - Instituto do Açúcar e do Álcool

LEA - "Late Embryogenesis Abundant"

MF - Matéria Fresca

Min - Minutos

MS - "Murashige, Skoog, 1962"

$\mathrm{NaHCO}_{3}-$ Carbonato de Sódio

PA - Poliamina

PCA - Ácido Perclórico

PEG - Polietilenoglicol

pH - Potencial de Hidrogênio lônico

PMSF - Fenil Metil Sulfonil Flúor

Put - Putrescina 
$\mathrm{p} / \mathrm{v}$ - Peso/Volume

PVPP - Polivinilpolipirrolidona

SAM - S-adenosil-metionina descarboxilada

Spd - Espermidina

Spm - Espermina

UFRRJ- Universidade Federal Rural do Rio de Janeiro

v/v - Volume/Volume 


\section{SUMÁRIO}

1 INTRODUÇÃO

1.1 O Sistema Cana-de-Açúcar

1.2 Embriogênese Somática 15

1.3 Multiplicação Celular 20

1.4 Aspectos Bioquímicos das Culturas 21

1.4.1 Carboidratos e Amido

1.4.2 Proteínas

1.4.3 Poliaminas

2 OBJETIVOS 30

2.1 Objetivo Geral 30

2.2 Objetivos Específicos 30

3 MATERIAIS E MÉTODOS

3.1 Material Vegetal 31

3.2 Experimento de Multiplicação celular 32

3.3 Análise de Carboidratos 33

3.4 Análise de Amido 34

3.5 Análise de Proteínas 34

3.6 Análise de Poliaminas 35

3.7 Análises Estatísticas 36

4 RESULTADOS

4.1 Curva de Crescimento 37

4.2 Carboidratos 38

4.3 Amido 42

4.4 Proteínas 43

4.5 Poliaminas 44

5 DISCUSSÃO

5.1 Curva de Crescimento 50

5.2 Carboidratos 52

5.3 Amido 54

5.4 Proteínas 56

5.5 Poliaminas 58

6 CONSIDERAÇÕES FINAIS 62 REFERÊNCIAS 


\section{INTRODUÇÃO}

\subsection{O Sistema Cana-de-Açúcar}

Cana-de-açúcar (Saccharum spp.) é planta alógama, gramínea perene pertencente à família Poaceae. É uma das mais antigas e mais importantes culturas do mundo (Vettore et al., 2003; Chengalrayan et al., 2005; Lakshmanan et al., 2005), tendo sua provável origem nas ilhas do Arquipélago da Polinésia (Cesnik, Miocque, 2004), onde foi domesticada e então disseminada por todo sudeste Asiático (Marques et al., 2009).

A cultura da cana-de-açúcar é responsável por grande produção de álcool e por $70 \%$ do açúcar mundial (Chengalrayan et al., 2005; Lakshmanan et al., 2005), além de ser fonte cada vez mais importante para a produção de biocombustíveis (McCormick et al., 2009).

O gênero Saccharum é formado por pelo menos cinco espécies: Saccharum officinarum, Saccharum sinensis, Saccharum barberi, Saccharum spontanium, Saccharum robusyum e as variedades de cana-de-açúcar cultivadas em escala comercial representam um híbrido multi-específico, que recebe a denominação Saccharum spp (Veiga et al., 2006). Como conseqüência dos cruzamentos interespecíficos, as cultivares produzidas possuem alto grau de poliploidia, possuindo número de cromossomos variando entre 100 e 130, sendo a maioria destes provenientes da espécie $S$. officinarum (Vettore et al., 2003).

A cultura da cana-de-açúcar é amplamente cultivada ao longo dos trópicos e subtrópicos e suas principais indústrias são encontradas no Brasil, China e Índia, sendo produzida comercialmente em muitos outros países (Snyman et al., 2011).

No Brasil, as primeiras mudas de cana-de-açúcar foram introduzidas em 1502, vindas da llha da Madeira, trazidas por Martim Afonso de Souza (Cesnik, Miocque, 2004), sendo o primeiro engenho de açúcar construído em 1532, na capitania de São Vicente. No século XVII o Brasil já era o maior produtor e fornecedor mundial de açúcar (Marques et al., 2009). Porém, em 1929 a economia açucareira no Brasil sofreu uma crise, devido à queda dos preços internacionais e ao aumento da utilização do açúcar de beterraba produzido na Europa (Veiga et al., 2006). 
Para atenuar esta crise, em 1931, o governo brasileiro tornou obrigatória a mistura de 5\% de álcool etílico à gasolina utilizada no país (Veiga et al., 2006). Então, em 1933 foi criado o Instituto do Açúcar e do Álcool- IAA que na década de 70 cria incentivos políticos para aumentar a produção e produtividade de cana-deaçúcar no Brasil (Santiago et al., 2006). Em 1975, buscando a diminuição da utilização de combustíveis fósseis e devido à pressão realizada pelo setor produtivo de cana-de-açúcar, o Governo Federal cria o Programa Nacional do Álcool PROÁLCOOL (Santiago et al., 2006), gerando subsídio para implantação de destilarias de álcool no país e para o desenvolvimento das plantações de cana-deaçúcar.

Em 1979, a indústria automobilística brasileira lançou no mercado seus primeiros modelos de carros movidos a álcool (Veiga et al., 2006). As vendas desses modelos chegaram a representar 95\% das vendas totais, em 1985 (Santiago et al., 2006). Mas, a partir de 1990 o setor sucroalcooleiro nacional volta a sofrer interferências políticas importantes, como a desregulamentação do setor e a extinção do IAA, tendo como consequência a liberação dos preços da cana-deaçúcar, do açúcar e do álcool. Além disso, a política econômica, com objetivo de controlar a inflação através de diversos planos econômicos, inclusive com congelamento de preços, também contribuiu para aumentar a crise no setor canavieiro (Santiago et al., 2006). A partir de 1986, houve ainda uma redução no percentual de participação dos veículos movidos a álcool no total de vendas, até atingir os mais baixos índices em 1997/98 (Veiga et al., 2006).

Contudo, em 2003, o sucesso do lançamento dos veículos flex fuel, cujas vendas em 2004 já representavam 20,2\% do total de vendas internas no país, novamente impulsionaram o consumo de álcool, aquecendo a produção de cana-deaçúcar (Veiga et al., 2006). Nota-se também que os recentes aumentos nos preços internacionais do petróleo têm influenciado positivamente a demanda mundial de álcool carburante (Veiga et al., 2006).

Hoje, o Brasil é o maior produtor e exportador mundial de açúcar refinado e álcool combustível obtidos a partir de cana-de-açúcar. De acordo com o terceiro levantamento da safra 2011/2012 feito pela Companhia Nacional de Abastecimento (Conab), a produção nacional está em torno de 572 milhões de toneladas. O Estado 
de São Paulo é o maior produtor do país, com 52,2\% da área nacional plantada (Conab, 2012).

Devido à sua importância na indústria agrícola global, um grande aporte de esforços e recursos tem sido direcionado para pesquisas voltadas ao setor sucroalcooleiro no País. Parte das pesquisas tem incidido sobre o melhoramento de cultivares de cana-de-açúcar por meio de reprodução vegetal e, mais recentemente, por meio da biotecnologia (Chengalrayan et al., 2005).

O alto nível de ploidia, requisitos específicos de clima para o florescimento e a definição de sementes, em conjunto com longo ciclo de vida, são as maiores limitações para a melhoria através de técnicas convencionais de melhoramento. Além disso, uma vez que muitas variedades de cana-de-açúcar não produzem sementes férteis, e devido a dificuldades de autofecundação e autocruzamento, a cultura é uma das espécies de plantas que não poderia ser produzida comercialmente sem intervenção humana (Asad et al., 2009).

Nesse contexto, a biotecnologia vegetal tem o potencial de superar problemas e possibilitar o melhoramento da cana-de-açúcar, por meio de técnicas de cultura de tecidos a nível celular e de engenharia genética a nível molecular, trazendo novas oportunidades para a produção de cultivares geneticamente superiores, com alta qualidade de plantio, tendo as características desejadas (Chengalrayan et al., 2005; Asad et al., 2009).

Técnicas in vitro para a propagação em massa de mudas viáveis de cana-deaçúcar via organogênese e/ou embriogênese somática (direta e indireta) são alvo de diversos projetos que visam o estudo e a compreensão da morfogênese in vitro nesta espécie (Lakshmanan et al., 2005; Snyman et al., 2011).

\subsection{Embriogênese Somática}

Em 2005, o periódico Science publicou uma edição comemorativa aos seus 125 anos, que versa sobre as grandes perguntas científicas que a humanidade ainda não conseguiu responder. Inicialmente 125 questões foram selecionadas e dentre estas as 25 perguntas mais importantes foram discutidas e publicadas na 
edição comemorativa. Uma destas questões foi: "Como uma única célula somática vegetal consegue se transformar numa planta completa?" (Kennedy, Norman, 2005). Essa indagação figura entre as questões de maior relevância científica que ainda se encontram sem resposta na atualidade (Vogel, 2005).

Em resumo, esta questão se remete ao conceito da totipotência em plantas, inerente às células vegetais, sendo a morfogênese in vitro o principal exemplo deste conceito. Na morfogênese in vitro, a embriogênese somática (ES) é um processo onde, células somáticas (já diferenciadas) isoladas ou em pequeno grupo dão origem a embriões (Tautorus et al., 1991), numa seqüência morfogenética que se aproxima aos eventos representativos da embriogênese zigótica (que é derivada da fusão de células gaméticas) (Floh et al., 2007).

Desde o princípio da cultura de tecidos vegetais, experimentos com a utilização dos mais variados tipos de explantes e distintas alterações nos meios de cultura para utilização in vitro têm sido testados na tentativa de desvendar os complexos processos moleculares, fisiológicos e bioquímicos que determinam a competência morfogenética em células vegetais. Passados cerca de meio século, esses processos metabólicos ainda não foram totalmente esclarecidos (Mordhorst et al.,1997).

Neste sentido, nossa hipótese de trabalho é que a compreensão dos parâmetros fisiológicos, bioquímicos e moleculares associados ao crescimento celular e desenvolvimento in vitro apresentam elevado potencial de aplicação no desenvolvimento e otimização de protocolos para embriogênese somática de canade-açúcar.

A embriogênese in vitro foi descrita pela primeira vez em 1958, por Steward e sua equipe e Reinert e sua equipe, independentemente, em Daucus carota (Floh et al., 2007). A cultura de tecidos de cana-de-açúcar foi iniciada no Havaí, em 1961 (Chengalrayan et al., 2005; Asad et al., 2009), e a embriogênese somática direta foi o caminho adotado pelos primeiros relatos sobre micropropagação dessa espécie (Snyman et al., 2011). Posteriormente, vários protocolos para embriogênese somática e organogênese, que regeneram plantas completas direta ou indiretamente, foram desenvolvidos usando calos derivados de explantes diversos como inflorescências imaturas, folhas jovens e meristemas apicais (Chengalrayan et al., 2005; Asad et al., 2009). 
Dois padrões básicos de expressão de embriogênese somática ocorrem in vitro. Um deles corresponde ao modelo direto, no qual os embriões somáticos originam-se dos tecidos-matrizes, sem a formação de estágios intermediários de calo (Guerra et al., 1999). O outro corresponde ao modelo indireto, no qual os embriões somáticos se formam a partir de um calo, que representa células em diferentes estágios de diferenciação e, consequentemente, com diferentes graus de determinação, podendo adquirir novas competências mediadas por mensageiros químicos específicos (Guerra et al., 1999). Estes processos envolvem mecanismos complexos de reativação celular, divisão, reprogramação do metabolismo e desenvolvimento (Fehér et al., 2003; Floh et al., 2007).

A modulação da embriogênese somática pode ser obtida em um sistema biotecnológico de dois ciclos básicos. O primeiro ciclo é o de indução e multiplicação, que se inicia com a indução de CE em meios de culturas contendo auxinas, principalmente o 2,4-D, e compreende a fase de multiplicação, em meios contendo auxinas em baixas concentrações. O segundo ciclo é o de maturação, que ocorre com a retirada da auxina do meio e é caracterizado pelo uso de promotores de maturação. Como produtos desse segundo ciclo são obtidos embriões somáticos maduros, passíveis de germinação in vitro e ex vitro ou que podem ser utilizados para produção de sementes sintéticas (Steiner et al., 2008) (Figura 1).

As condições para promover a embriogênese somática estão relacionadas com a presença de reguladores de crescimento, estresses osmóticos, alterações de $\mathrm{pH}$, choques térmicos e tratamentos com diferentes substâncias, sendo as auxinas referenciadas como essenciais na indução do processo (Floh et al., 2007). Auxinas são uma das mais importantes classes de fitormônios, uma vez que são os reguladores chave de vários aspectos do crescimento e desenvolvimento das plantas (Pieruzzi et al., 2011).

Atualmente, a embriogênese somática é induzida em explantes de cana-deaçúcar utilizando, principalmente, o ácido 2,4-diclorofenoxiacético, uma auxina sintética. Esses embriões se desenvolvem a partir de uma única célula, pequena, de paredes finas e rica em citoplasma, que contêm muitos vacúolos e grânulos de amido (Chengalrayan et al., 2005; Asad et al., 2009; Snyman et al., 2011). 
Figura 1 - Modulação da embriogênese somática em espécies arbóreas.

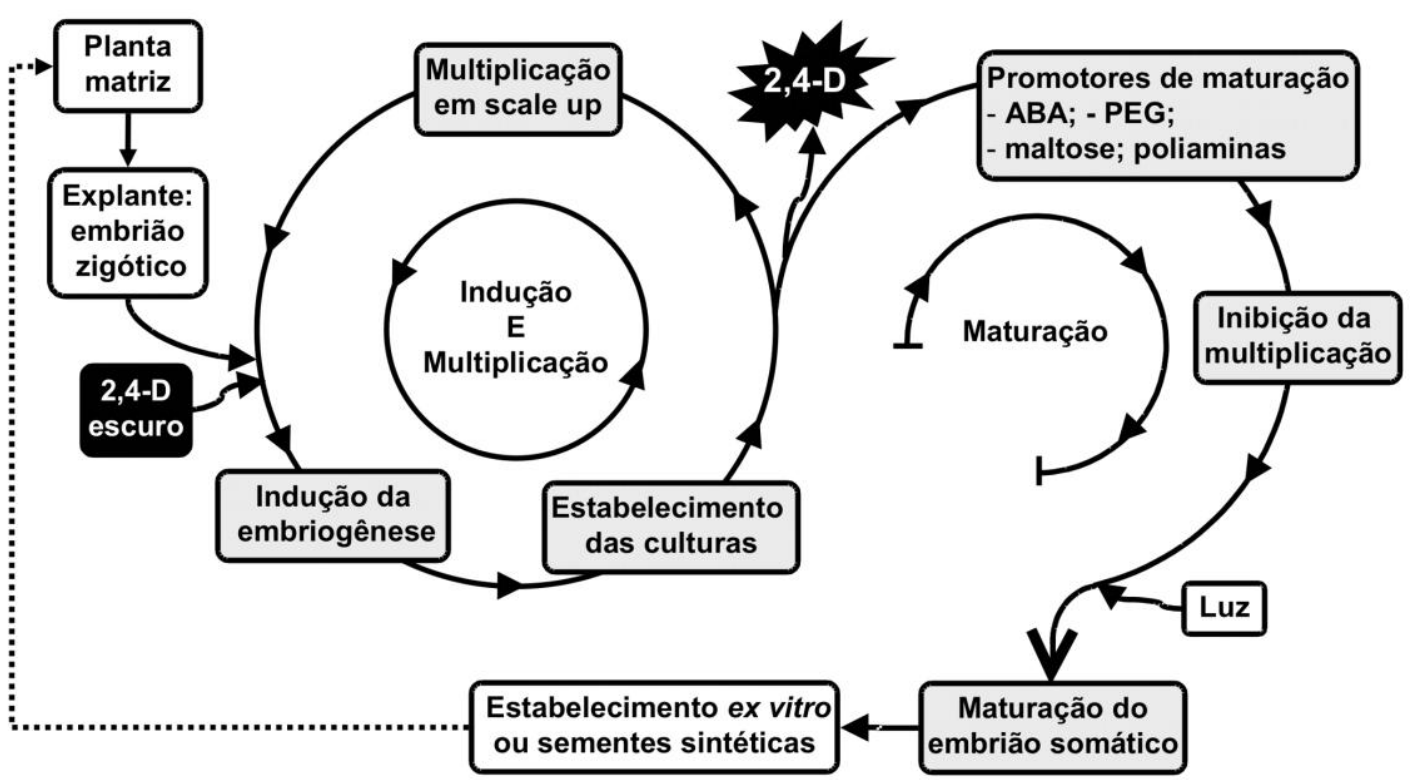

(1) ciclos de indução e multiplicação e (2) ciclo de maturação.

FONTE: adaptada de Steiner et al., 2008.

Além das condições de cultivo, também devem ser considerados como fundamentais, o explante inicial, incluindo o seu genótipo, o estádio de desenvolvimento e as condições fisiológicas, como por exemplo, o conteúdo hormonal endógeno do material. Portanto, a embriogênese pode ser definida como um processo multifatorial e altamente complexo (Floh et al., 2007).

Comparada às demais técnicas de micropropagação, a embriogênese somática apresenta as seguintes vantagens: a) permite a obtenção de uma grande quantidade de propágulos (embriões somáticos); b) o sistema permite um alto grau de automatização, possibilitando baixar os custos por unidade produzida, através da utilização de biorreatores; c) os embriões somáticos podem ser produzidos de forma sincronizada, com alto grau de uniformização e pureza genética; e d) pode ser utilizada como uma ferramenta integrada a programas de melhoramento genético, em especial quando associada às técnicas de criopreservação e engenharia genética (Guerra et al., 1999; Lipavská, Konrádová, 2004). Entretanto, a principal limitação dos sistemas de embriogênese somática, desenvolvidos para várias espécies, é a variação somaclonal ocorrida após sucessivas subculturas, afetando o desenvolvimento das plantas produzidas (Lakshmanan et al., 2005). 
Conforme a literatura, a capacidade das técnicas de cultivo in vitro de produzir um grande número de plantas rapidamente, tem sido explorada para aplicação comercial em indústrias de açúcar em todo o mundo (Snyman et al., 2011). Além disso, foi observado que a aclimatação de plantas de cana-de-açúcar produzidas in vitro geralmente é bem sucedida. Mais de $85 \%$ das plantas derivadas de embriões somáticos sobreviveram às condições de transferência para estufa. Após a aclimatação ao ambiente de estufa, essas plantas foram transferidas para condições de campo onde a sobrevivência foi superior a 90\% (Snyman et al., 2011).

Para produção de plantas transgênicas através de qualquer método de transformação (físico, químico ou biológico) é necessário sistemas de regeneração de plantas altamente eficientes e confiáveis (Asad et al., 2009). O método com potencial de maior taxa de multiplicação é a regeneração por meio de embriogênese somática (Hoenemann et al., 2010). Os calos embriogênicos têm sido frequentemente usados em experimentos de transferência de genes com monocotiledôneas, pois podem ser manipulados para produzir plantas transformadas férteis (Grando et al., 2002).

Além de apoiar programas de engenharia genética, protocolos bem estabelecidos para manipulações da embriogênese somática in vitro oferecem um modelo bastante interessante para estudos básicos de fisiologia, biologia celular, bioquímica, genética da diferenciação e morfogênese em vegetais (Floh et al., 2007; Nieves et al., 2008). Além disso, a embriogênese somática constitui estratégia única para lidar com as limitações de diversidade genética estreita, como a propagação e o armazenamento (Silveira et al., 2002; Snyman et al., 2011).

Durante os últimos anos, muitos estudos têm sido publicados analisando a embriogênese somática relacionada a um perfil de expressão gênica. No entanto, estudos que visam uma melhoria dos protocolos para a propagação em massa são realizados insuficientemente (Hoenemann et al., 2010). Embora existam relatos de protocolos para inúmeras espécies, os seus avanços ainda são limitados pela falta da compreensão dos estímulos e condições necessárias para sua indução e controle da embriogênese somática (Lipavská, Konrádová, 2004; Floh et al., 2007). 


\subsection{Multiplicação Celular}

O desenvolvimento do embrião somático, assim como do embrião zigótico, ocorre em uma ordem sequencial, onde estágios podem ser diferenciados: a divisão celular, a diferenciação e a maturação (Nieves et al., 2008). Dentre as etapas da embriogênese, a indução e multiplicação (divisão celular) de CE é uma das etapas mais importantes do protocolo (Guerra et al., 1999).

A habilidade para indução de calos embriogênicos é influenciada pelo genótipo, assim como sua resposta morfogenética e a habilidade de regenerar plantas, indicando que estes critérios são genótipo-dependentes (Lima et al., 2001; Cidade et al., 2006; Lakshmanan, 2006). De acordo com Gandonou et al. (2005), por ser a capacidade embriogênica uma característica estável desde a primeira geração, seria possível prognosticar essa capacidade em uma determinada linhagem por avaliar a taxa embriogênica de seus ancestrais.

As auxinas são as substâncias responsáveis pelo desencadeamento dos processos de desdiferenciação (modelos indiretos) e rediferenciação (modelos diretos) durante a indução, alterando a determinação e conferindo novas competências às células responsivas presentes nos explantes (Guerra et al., 1999).

Em nível celular, auxinas controlam a divisão, elongação e diferenciação, bem como a polaridade de células vegetais (Pieruzzi et al., 2011). Atuam de duas maneiras durante o crescimento celular: estimulando a acidificação da parede celular que resulta em elevada extensibilidade e induzindo a transcrição de mRNAs que codificam proteínas associadas com o crescimento celular (Richard et al., 2002).

O 2,4-D, principal auxina utilizada na embriogênese somática em cana-deaçúcar, quando acima de uma determinada concentração, pode assumir um duplo efeito nas culturas, atuando como auxina e como um agente de estresse (Floh et al., 2007). Então, tecidos de folhas jovens de cana-de-açúcar cultivadas in vitro na presença de 2,4-D originam dois tipos de calos na embriogênese indireta: os calos embriogênicos, caracterizados por apresentarem aspecto nodular opaco, e facilmente destacável, e os calos não-embriogênicos que são translúcidos e mucilaginosos (Lakshmanan, 2006). 
O início e a manutenção de CE foram monitorados em um grande número de plantas, incluindo muitos membros da família Poaceae (gramíneas). Calos embriogênicos apresentam maior velocidade no desenvolvimento e formam plantas por embriogênese somáticas, enquanto os calos não-embriogênicos crescem lentamente, de forma desordenada, e formam brotos ou raízes por organogênese (Nieves et al., 2003).

O crescimento dinâmico em CE, na maioria dos casos é descrito por uma curva sigmóide mostrando a fase Lag, seguida pelas fases exponencial, linear e estacionária (Silveira et al., 2004a). A fase Lag é considerada um período de adaptação das células ao novo meio de cultura. Nas fases exponencial e linear, a alta razão de divisão celular resulta no crescimento das culturas. $\mathrm{Na}$ fase estacionaria a divisão celular é gradativamente reduzida (Silveira et al., 2004a).

O crescimento de CE é geralmente associado com algumas mudanças bioquímicas, como a síntese e mobilização de proteínas, carboidratos, lipídios e ácidos nucléicos. O nível dessas substâncias depende das diferentes fases de crescimento e de suas funções no suprimento energético para o crescimento celular (Silveira et al., 2004a).

\subsection{Aspectos Bioquímicos da Embriogênese Somática}

Calos embriogênicos e não-embriogênicos podem ser visualmente diferenciados por sua morfologia, mas pouco se sabe sobre os eventos bioquímicos e moleculares que ocorrem quando as células somáticas se tornam competentes para produzir embriões somáticos (Nieves et al., 2003).

Assim, informações valiosas podem ser obtidas através do monitoramento de variáveis bioquímicas, uma vez que estas têm sido demonstradas como potenciais discriminadores entre tecidos embriogênicos e não-embriogênicos (Nieves et al., 2008). Nieves et al. (2003) observaram que CE de cana-de-açúcar apresentam maior atividade metabólica que as CNE.

A síntese e o acúmulo de substâncias de reserva representam um estádio importante na embriogênese zigótica, pois permitem 0 armazenamento de compostos que serão utilizados pelo embrião até o estabelecimento da autotrofia por 
parte da plântula recém-formada. Estes compostos podem ser considerados marcadores confiáveis da qualidade dos embriões zigóticos e somáticos (Merkle et al., 1995).

Um melhor conhecimento dos aspectos bioquímicos das culturas podem ainda ter aplicações úteis na caracterização das diferentes etapas da embriogênese somática. Assim, calos regeneráveis e não regeneráveis fornecem um sistema experimental útil para estudar o mecanismo de morfogênese in vitro (Nieves et al., 2003).

Além disso, uma melhor compreensão de eventos bioquímicos e moleculares que ocorrem durante a embriogênese somática é essencial para aumentar a eficiência do desenvolvimento de embriões (Silveira et al., 2004a, 2006) e gerar prováveis marcadores bioquímicos para a competência embriogênica e qualidade dos embriões formados (Klimaszewska et al., 2004). Dentre os compostos endógenos com importância para o desenvolvimento da embriogênese somática, destacam-se os carboidratos e amido, proteínas e poliaminas, que atuam em diferentes fases do processo morfogenético.

\subsubsection{Carboidratos e Amido}

Os carboidratos são fotossintetizados em plantas, inicialmente, como monossacarídeos, que são então transformados em dissacarídeos, trissacarídeos e açúcares alcoóis (Gómez-González et al., 2010). Na maioria das plantas a sacarose é a forma principal de transporte de carboidratos e o amido é o principal carboidrato de reserva (Geigenberger et al., 2004).

A função primária dos açúcares é servir de fonte de energia para alterações metabólicas ou participar como precursores moleculares na biossíntese de lipídios, proteínas, antioxidantes e polissacarídeos, fornecendo moléculas de carbono (Pescador et al., 2008; Gómez-González et al., 2010).

Os carboidratos, além de atuar como substratos para o crescimento, podem também regular a morfogênese e a diferenciação celular nos vegetais, desempenhando papel chave na estrutura da parede celular (Smeekens, 2000). 
Evidências indicam ainda que o suprimento de açúcares pode regular a expressão de genes envolvidos em processos como a floração, fotossíntese, glicólise, metabolismo do nitrogênio e regulação do ciclo celular (Smeekens, 2000), podendo, esta regulação, ocorrer nos níveis de transcrição, tradução e pós-tradução (Delrot, 2000; Rapaka et al., 2008).

Além disso, durante todas as fases de desenvolvimento do embrião, os polissacarídeos parecem desempenhar um papel importante (Lipavská, Konrádová, 2004). Em alguns casos, os níveis de açúcar ou seu fluxo parecem determinar a ocorrência de um determinado evento ou o momento em que ele ocorre, como em processos de germinação das sementes (Gibson, 2005). Adicionalmente, o acúmulo de reservas adequadas é vital para a embriogênese somática de plantas, assim como para a conversão em plântulas, após a obtenção de embriões cotiledonares (Flinn et al., 1993).

Estoque de carboidratos como amido e sacarose, que desempenham importantes papéis no metabolismo celular, também contribuem para a reserva total de carboidratos nas plantas (Opsahl, Benner, 1999).

Diferentes autores têm relatado a presença de amido nas células vegetais no início do processo de desenvolvimento in vitro. O possível papel desse polissacarídeo nestes processos ainda não está claro, embora tenha sido sugerido que poderia atuar como uma fonte de energia ou como um agente osmótico essencial para o desenvolvimento. No entanto, a metabolização destes grãos de amido foi reportada quando foram iniciados os processos de organogênese e embriogênese somática (Martin et al., 2000).

$\mathrm{Na}$ maioria das plantas, durante o processo de formação da semente e/ou do embrião, a glicose e a frutose também estão presentes na fase inicial de desenvolvimento embrionário, e diminuem gradualmente, desaparecendo na maturidade. Contrariamente, a sacarose é estocada na fase final do desenvolvimento embrionário (Focks, Benning, 1998). Estes resultados sugerem que cada carboidratos possui importância em determinada fase de desenvolvimento do embrião. Neste sentido, a variação dos carboidratos solúveis e do amido na embriogênese somática pode fornecer informações importantes sobre a conversão de embriões somáticos em plântulas (Pescador et al., 2008). Estudos em Acca sellowiana demonstraram alta quantidade de sacarose, frutose e outros carboidratos 
em diferentes estágios do desenvolvimento de embriões somáticos (Pescador et al., 2008).

Em sistemas de cultura in vitro faz-se necessário o fornecimento externo de carbono, uma vez que as CE são mantidas no escuro, sendo basicamente heterotróficas. Neste contexto, os processos de síntese e armazenamento de compostos relacionados com a embriogênese ocorrem de forma diferenciada nos sistemas de embriogênese somática e zigótica, pois embriogênese zigótica possuem uma relação fonte-dreno com a planta matriz até a maturação fisiológica do embrião (Sghaier-Hammami et al., 2009).

Para a obtenção de embriões somáticos em cana-de-açúcar, bem como em outras espécies, o fornecimento externo de carbono ocorre normalmente por meio da adição de sacarose ao meio de cultivo inicial, ao qual o explante será exposto (Mordocco et al., 2009). Parte da sacarose contida no meio de cultura sofre degradação extracelular, sendo convertida e disponibilizada para as células (Martin et al., 2007). As moléculas de sacaroses interiorizadas representam uma importante fonte de armazenamento, e após sua hidrólise pela ação de invertases, apresentamse, em grande parte dos sistemas biológicos, como a principal fonte de carbono para a síntese de carboidratos metabolicamente ativos, polissacarídeos estruturais e de armazenamento (Martin et al., 2007).

A alocação dos carboidratos para o interior das células vegetais em culturas de calos com potencial embriogênico tem recebido especial atenção, uma vez que os tecidos que normalmente efetuam esse transporte em plantas, como o floema e as células parenquimáticas, ainda não se encontram diferenciados nos calos (Gutiérrez-Miceli et al., 2005).

O conhecimento bioquímico, em especial dos conteúdos de carboidratos solúveis, em embriões somáticos comparados ao seu análogo zigótico, pode oferecer informações que ajudariam a prever a fidelidade de embriões somáticos na regeneração de plantas, especialmente na etapa de conversão (Chanprame et al., 1998).

O uso de culturas de calos pode ser preferível no estudo do metabolismo de acúmulo de sacarose, por representar uma grande possibilidade de controle e manipulação do meio de cultivo, facilitando o controle das condições ambientais e 
viabilizar o uso de diferentes cultivares simultaneamente (Gutiérrez-Miceli et al., 2005).

A utilização do cultivo in vitro de calos de cana-de-açúcar apresenta-se, dessa forma, como um modelo experimental apropriado para a caracterização qualitativa e quantitativa do metabolismo de carboidratos em calos embriogênicos e nãoembriogênicos, e para identificação de possíveis marcadores bioquímicos da embriogênese, conforme estudado em muitas espécies (Martin et al., 2007).

Para entender o papel dos carboidratos durante a embriogênese somática, e nas diferentes fases desta, é importante obter informações sobre seus níveis endógenos e seu metabolismo para propor tratamentos que melhorem ou favoreçam o desenvolvimento do embrião. Entretanto, até o momento, apenas um número pequeno de relatos está disponível associando embriogênese somática e metabolismo endógeno de carboidratos (Lipavská, Konrádová, 2004).

\subsubsection{Proteínas}

Proteínas são macromoléculas constituídas a partir de 20 aminoácidos canônicos, juntamente com selenocisteína e pirrolisina que muitas vezes são referidas como $21^{\circ}$ e $22^{\circ}$ aminoácidos (Rodgers, Shiozawa, 2008).

As proteínas desempenham um papel importante no metabolismo (Nieves et al., 2008). Entre as funções e influências de moléculas regulatórias, o papel das proteínas nos processos de diferenciação celular é de particular interesse (SaareSurminski et al., 2000). O ciclo celular é realizado pela síntese de várias proteínas novas que atuam em mudanças morfológicas e bioquímicas nas células durante a atividade mitótica (Silveira et al., 2004a).

Dessa forma, existem vários estudos relacionados à síntese e ao acúmulo de proteínas de armazenamento em diferentes estágios durante a embriogênese somática, além de estudos relacionados à mudanças em seu perfil ou em sua função como receptores (Santa-Catarina et al., 2006; Nieves et al., 2008). Em geral, o aumento do acúmulo de proteínas é observado durante o desenvolvimento do embrião, conforme observado na embriogênese zigótica em Ocotea catharinensis (Santa-Catarina et al., 2006). 
Esse aumento protéico é resultado, principalmente, da síntese de proteínas LEA ("late embryogenesis abundant") e de proteínas de reserva (Bewley, Black, 1994). As proteínas LEA são classificadas em cinco grupos em virtude da similaridade de suas seqüências de aminoácidos. Elas apresentam baixa complexidade e uma grande afinidade com as moléculas de água, atuando na proteção à desidratação da semente (Boudet et al., 2006), representando portanto um papel fundamental na manutenção da viabilidade dos embriões.

As proteínas LEA também se acumulam em altos níveis no desenvolvimento de sementes, durante a maturação e na desidratação de tecidos vegetativos de plantas em restabelecimento e são extremamente diversificadas em termos de variabilidade genotípica, regulação e localização em nível celular e tecidual (Bewley, Black, 1994; Boudet et al., 2006).

A capacidade embriogênica dos calos e suspensões celulares de formar embriões somáticos indica que existe uma diferença no controle da expressão genética de proteínas entre células embriogênicas e não-embriogênicas (Oropeza et al., 2001). Assim, um marcador bioquímico poderia ser útil, a fim de identificar esta expressão gênica diferencial antes de qualquer alteração morfológica ser aparente (Oropeza et al., 2001).

Perfis de proteínas têm sido utilizados como marcadores moleculares com sucesso em culturas de várias espécies. Embora sejam menos polimórficos que os marcadores de DNA, informações diretas podem ser adquiridas sobre a variabilidade genética para características alvo (Rodríguez et al., 2011).

Neste contexto, o estudo do metabolismo e do armazenamento de proteínas pode ser utilizado para avaliar a qualidade de células e embriões somáticos (LeluWalter et al., 2008). Padrões protéicos vêm sendo utilizados como marcadores da competência das $\mathrm{CE}$, ocorrendo várias diferenças nos perfis protéicos entre CE e CNE (Kormuták, Vookova, 1997). Neste sentido, o uso de proteínas como marcadores para monitorar e compreender as diferentes respostas biológicas apresenta-se como uma alternativa para o desenvolvimento de biotecnologias aplicadas a cultura da cana-de-açúcar. 


\subsubsection{Poliaminas (PAs)}

As PAs são aminas policatiônicas alifáticas de baixo peso molecular (SantaCatarina et al., 2006; Nieves et al., 2008), contendo cargas positivas nos seus átomos de nitrogênio, uma propriedade que facilita sua interação com macromoléculas como DNA e RNA, fosfolipídios, componentes da parede celular e proteínas (Steiner et al., 2007; Pieruzzi et al., 2011).

Elas estão presentes em diversos organismos tais como bactérias, fungos, animais e vegetais superiores (Wallace et al., 2003). Nos vegetais as principais PAs presentes são putrescina (Put), espermidina (Spd) e espermina (Spm) (Silveira et al., 2004a, 2006; Pieruzzi et al., 2011), estando em todos os compartimentos celulares, indicando sua participação em diversos processos fundamentais na célula. (SantaCatarina et al., 2006; Silveira et al., 2006; Steiner et al., 2007; Nieves et al., 2008).

O metabolismo de PAs envolve: (1) a biossíntese de Put a partir de arginina e ornitina pelas enzimas arginina descarboxilase e ornitina descarboxilase, respectivamente; (2) a conversão de Put em Spd e, subsequentemente, em Spm por adições sucessivas de grupos aminopropil a partir da S-adenosil-metionina (SAM), que é produto da reação da SAM descarboxilase (SAMDC); e (3) o catabolismo de Put, Spd e Spm por diamina e PA oxidases (Figura 2) (Minocha et al., 2004; Kusano et al., 2008).

Pode-se citar um amplo espectro de atividades biológicas em que as PAs participam, tais como a regulação da expressão gênica, a modulação de sinal, a proliferação celular e a estabilização de membrana (Silveira et al., 2006; SantaCatarina et al., 2007; Pieruzzi et al., 2011).

Esses papéis têm sido associados com o controle da divisão celular, a embriogênese, a formação de raízes, o desenvolvimento floral, o desenvolvimento e amadurecimento dos frutos, o metabolismo secundário, a senescência e as respostas a estresses bióticos e abióticos. Mais recentemente, PAs foram encontrados também regulando a morte celular programada e a apoptose (Bais, Ravishankar, 2002). 
Figura 2 - Via metabólica de poliaminas em plantas.

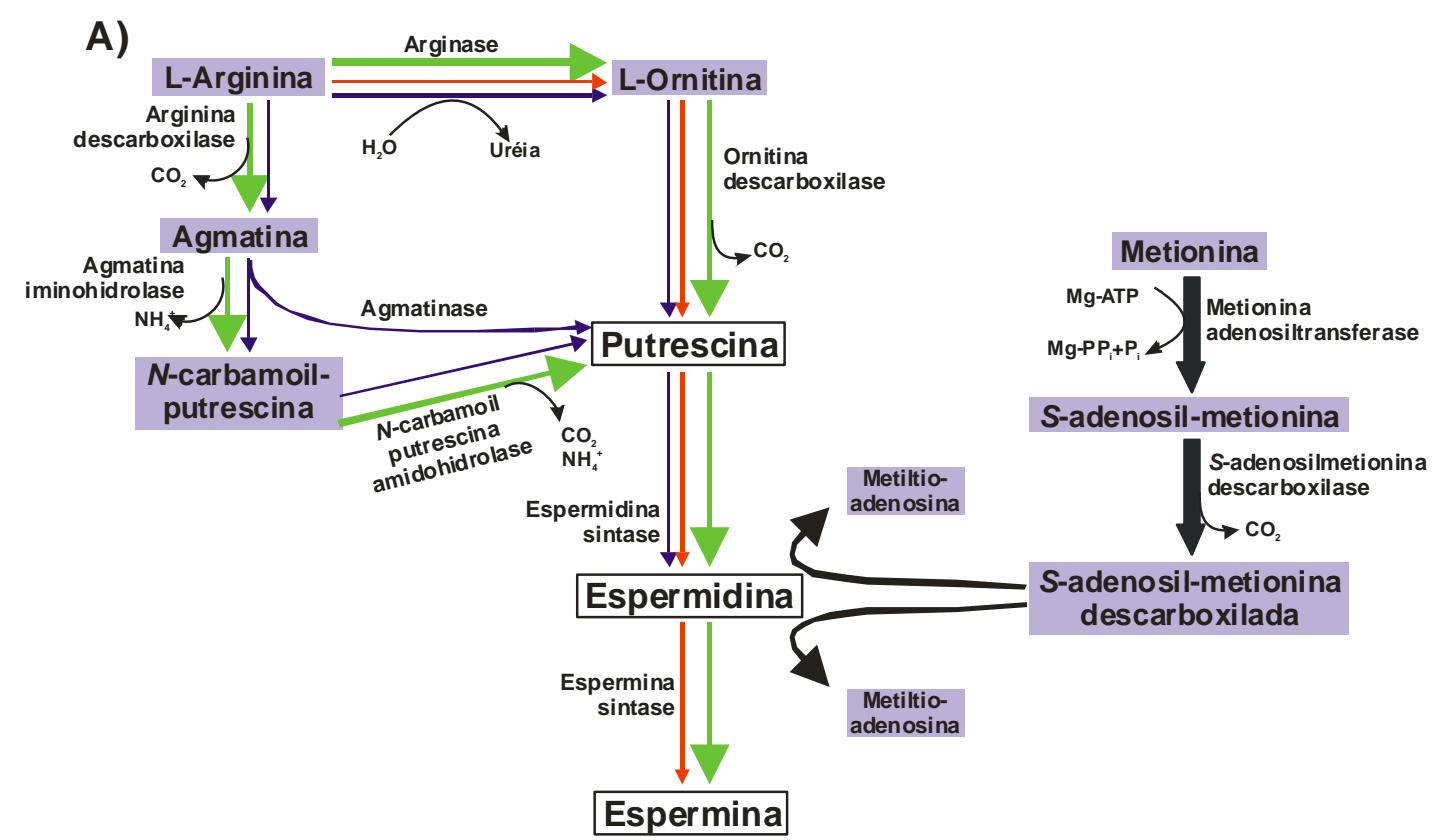

B)

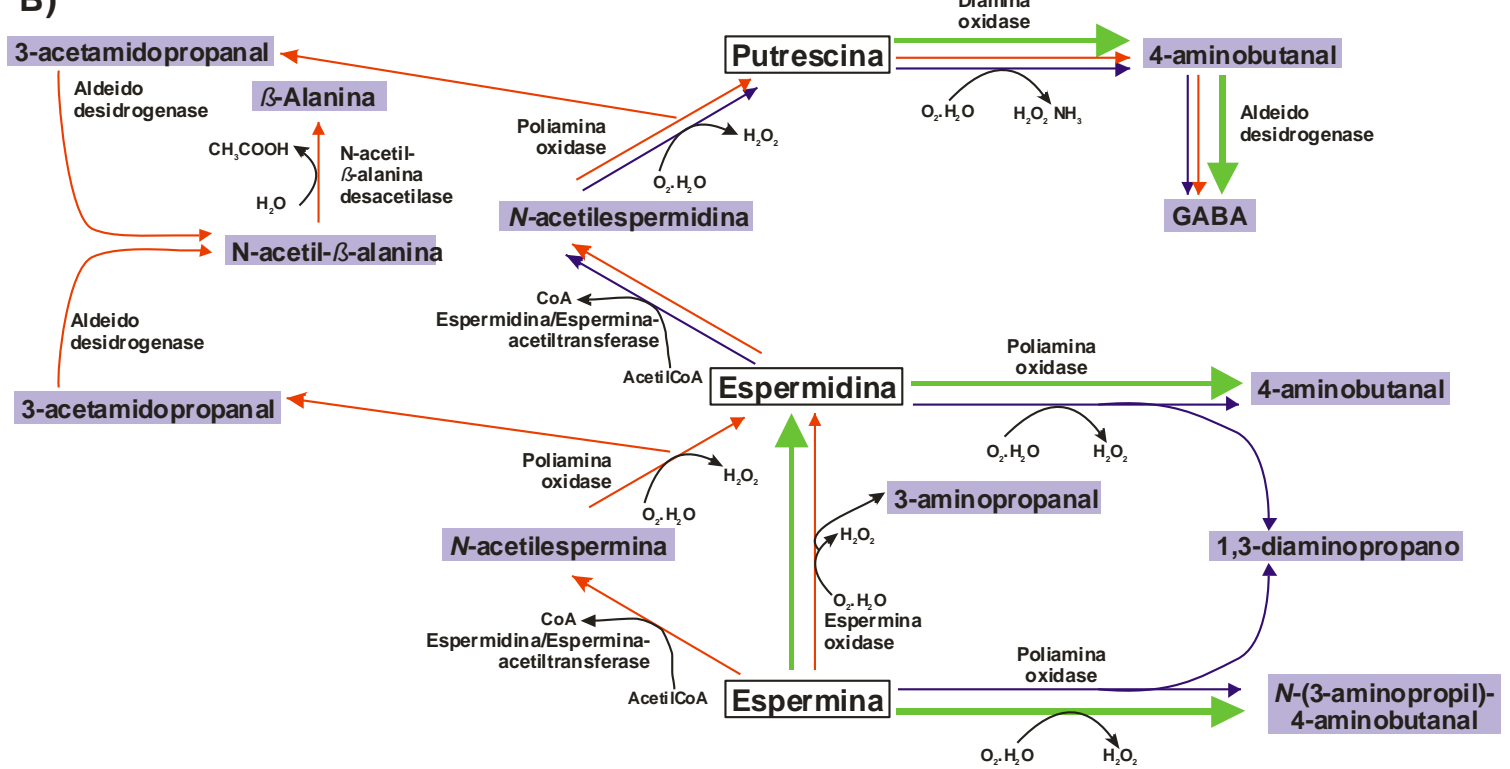

A) biossíntese e B) degradação. Setas verdes correspondem às vias presentes em plantas. Setas azuis e vermelhas representam vias presentes em bactérias e animais, respectivamente.

FONTE: Adaptado de Kusano et al. (2008).

Alguns autores propuseram que PAs e os compostos a elas relacionados podem ser considerados como tipos de reguladores de crescimento hormonal ou mensageiros secundários em muitos processos, incluindo a organogênese e a embriogênese, apesar de serem encontrados nas células vegetais em níveis significativamente superiores aos dos hormônios vegetais (Bais, Ravishankar, 2002). 
Diferenças significativas foram observadas na exigência de PAs entre os diferentes genótipos, indicando que os perfis destes compostos podem ser dependentes do genótipo (Silveira et al., 2004b). Além de estudos que avaliaram o efeito de uma única PA, outros estudos associam eventos fisiológicos nas plantas com a relação entre duas ou mais PAs (Pieruzzi et al., 2011).

Durante os processos de embriogênese somática e zigóticos, PAs têm sido usadas como biomarcadores do desenvolvimento (Minocha et al., 1999). Tem sido proposto que a relação Put: Spd é um importante biomarcador da capacidade de regeneração em plantas (Pieruzzi et al., 2011). Estão disponíveis dados limitados descrevendo as variações nos níveis de PAs e seus modos de ação nos vários processos morfogenéticos (Silveira et al., 2004b; Santa-Catarina et al., 2006; Nieves et al., 2008). 


\section{OBJETIVOS}

\subsection{Objetivo Geral}

O trabalho tem como objetivo estudar os aspectos bioquímicos durante a fase de multiplicação celular, que antecede a formação de embriões somáticos, com o intuito de adquirir conhecimento sobre o desenvolvimento das células de cana-deaçúcar da variedade SP80-3280, para um melhor entendimento da embriogênese somática nessa espécie.

\subsection{Objetivos Específicos}

- Monitorar o desenvolvimento celular de CE e CNE, durante a curva de crescimento celular;

- Estudar o perfil de carboidratos e de amido em CE e CNE, durante a multiplicação celular;

- Estudar o perfil de proteínas em CE e CNE, durante a multiplicação celular;

- Estudar o perfil das PAs em CE e CNE, durante a multiplicação celular. 


\section{MATERIAIS E MÉTODOS}

\subsection{Material Vegetal}

Foram utilizados toletes da cultivar SP80-3280, gentilmente cedidos pela UFRRJ/Campos. Os toletes foram separados de acordo com suas gemas laterais e plantados em bandejas contendo substrato comercial esterilizado PlantMax ${ }^{\circledR}$. As bandejas foram mantidas em temperatura e fotoperíodo ambientes, sendo os toletes regados diariamente com água pura, até que as plantas geradas atingissem aproximadamente $30 \mathrm{~cm}$ de altura (entre dois e três meses de cultivo) (Figura 3), quando foram individualizadas e utilizadas para o estabelecimento de CE e CNE.

Essas plantas foram lavadas e suas folhas mais externas retiradas (figura 3). Os cilindros centrais resultantes foram submetidos à desinfecção com um min em etanol 70\%, seguido de $15 \mathrm{~min}$ em água sanitária comercial 40\%, sendo posteriormente lavados em capela de fluxo laminar com água destilada autoclavada. Então os cilindros centrais foram seccionados em discos de aproximadamente 3-4 mm que foram utilizados como explantes.

Figura 3 - Esquema da obtenção dos explantes primários na regeneração de plantas via embriogênese somática em cultivares de cana-de-açúcar.

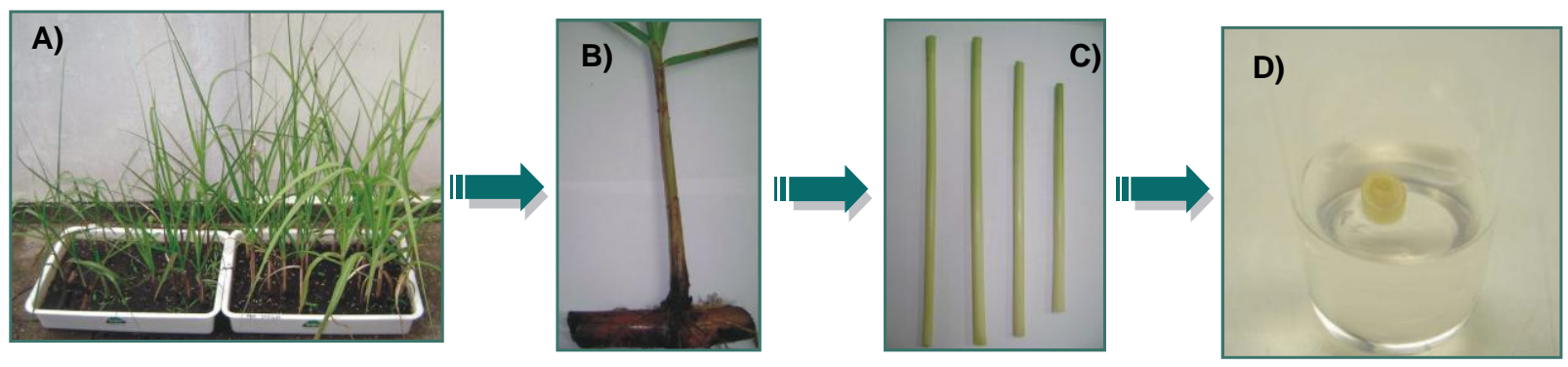

A) Plantas crescidas em substrato comercial com aproximadamente $30 \mathrm{~cm}$ de altura. B) Porção de interesse da planta. C) Porção medular formada pelas folhas mais jovens. D) Seção transversal (TS) como explante na indução dos calos.

FONTE: Fim, 2012.

Os explantes foram inoculados individualmente em tubos de ensaio contendo $20 \mathrm{~mL}$ de meio de cultura MS (Murashige, Skoog, 1962) suplementado com sacarose $\left(30 \mathrm{~g} \cdot \mathrm{L}^{-1}\right)$, phytagel $\left(2 \mathrm{~g} \cdot \mathrm{L}^{-1}\right)$ e $10 \mu \mathrm{M}$ de 2,4-D, com pH ajustado em 5,8 (Figura 3). Os tubos inoculados foram mantidos em estufa do tipo BOD, a 
temperatura de $25 \pm 1^{\circ} \mathrm{C}$, no escuro, para a indução de CE e CNE, que são o material vegetal para as análises realizadas no presente trabalho.

Essas culturas foram estabelecidas em colaboração com o Laboratório de Biotecnologia LBT/CBB/UENF e mantidos em subcultivos periódicos (21 dias) no Laboratório de Biologia Celular de Plantas BIOCEL/IB/USP.

\subsection{Experimento de Multiplicação celular}

Após a indução, as culturas obtidas foram separadas em calos embriogênicos e não-embriogênicos, os quais foram inoculados separadamente em meio de cultura MS, suplementado com $30 \mathrm{~g} \cdot \mathrm{L}^{-1}$ de sacarose, $2 \mathrm{~g} \cdot \mathrm{L}^{-1}$ de phytagel e $10 \mu \mathrm{M}$ de 2,4-D, com pH ajustado para 5,8. Estes foram então mantidos em estufa do tipo BOD, no escuro, com temperatura de $25 \pm 1 \stackrel{\circ}{ } \mathrm{C}$, para acompanhamento da multiplicação celular.

Foram preparadas 36 placas de Petri para cada tipo celular (CE, CNE) contendo $25 \mathrm{~mL}$ do respectivo meio e, em cada placa, foram inoculadas cinco colônias celulares, com 200 mg cada.

Em intervalos de quatro dias, durante 32 dias, foram retiradas quatro placas de cada tipo celular e suas colônias tiveram a matéria fresca (MF) determinada. Esses dados foram utilizados para estabelecer a curva de crescimento de cada tipo celular.

Depois da determinação de MF, em cada intervalo de quatro dias, durante os 32 dias do experimento, as colônias foram isoladas em amostras de $300 \mathrm{mg}$, sendo essas congeladas a $-20{ }^{\circ} \mathrm{C}$, para posteriores determinações bioquímicas de carboidratos, amido, proteínas e poliaminas. 


\subsection{Análise de Carboidratos}

A determinação de carboidratos foi realizada de acordo com a metodologia proposta por Filson, Dawson-Andoh (2009), com modificações.

Amostras de $300 \mathrm{mg}$ das CE e CNE foram maceradas a $4{ }^{\circ} \mathrm{C}$, em triplicatas, com solução composta por $1 \mathrm{~mL}$ de etanol (EtOH) 80\%, 3\% (p/v) de polivinilpolipirrolidona (PVPP) e 1\% (p/v) de ácido ascórbico. Foram então agitadas e incubadas a $70^{\circ} \mathrm{C}$ por $90 \mathrm{~min}$.

Após serem incubados, os macerados foram centrifugados a 14000 rpm por $10 \min$ a $4{ }^{\circ} \mathrm{C}$. Então os sobrenadantes foram coletados, os precipitados ressuspendidos em $1 \mathrm{~mL}$ de $\mathrm{EtOH} 80 \%$ e centrifugados novamente, nas mesmas condições anteriores. Os sobrenadantes resultantes foram adicionados aos provenientes da primeira centrifugação e armazenados a $-20 \stackrel{\circ}{ } \mathrm{C}$.

Os carboidratos foram identificados e quantificados por HPLC usando um detector de espalhamento de luz (ELSD-LT II), com configuração do detector fixada em: temperatura à $40^{\circ} \mathrm{C}$; pressão de $\mathrm{N} 2$ em 350 kPa, ganho 9 e filtro 4.

Foi utilizada, como fase estacionária, a coluna Prevail Carbohydrate ES $5 \mu \mathrm{m}$ (250 x 4,6mm), com uma pré coluna do tipo Prevail Carbohydrate ES $5 \mu \mathrm{m}(7,5 \mathrm{x}$ $4,6 \mathrm{~mm})\left(\right.$ Allech $\left.^{\circledR}\right)$. A temperatura do forno de colunas foi mantida a $25^{\circ} \mathrm{C}$.

Como solventes, que representam a fase móvel, foram utilizados: Água Milli $Q$, como solvente A, e acetonitrila $100 \%$, como solvente $B$, sendo ambas as soluções submetidas a filtração prévia, em filtros de $0,2 \mu \mathrm{m}$. A corrida foi realizada em gradiente isocrático ajustado para $85 \%$ de solvente $B$ durante $30 \mathrm{~min}$. O fluxo de corrida foi de $1 \mathrm{~mL} \cdot \mathrm{min}^{-1}$ e o volume da amostra injetado foi $5 \mu \mathrm{L}$.

As áreas e tempos de retenção dos picos de carboidratos foram avaliados por comparação com padrões em diferentes concentrações. Os padrões utilizados são provenientes do Kit CARB 10 (SIGMA-ALDRICH®), em concentrações entre $0,08 \mathrm{mg} \cdot \mathrm{mL}^{-1}$ e $5 \mathrm{mg} \cdot \mathrm{mL}^{-1}$, para determinação de Frutose, Glicose e Sacarose. 


\subsection{Análise de Amido}

Os precipitados restantes da extração de carboidratos foram utilizados para as análises de amido. A extração e dosagem do amido foram realizadas segundo a metodologia de McCready et al. (1950).

Para isso, os precipitados foram lavados duas vezes em 1,4 $\mathrm{mL}$ de etanol $80 \%$ a $80^{\circ} \mathrm{C}$, centrifugados a $14000 \mathrm{rpm}$, por $15 \mathrm{~min}$ a $4^{\circ} \mathrm{C}$ e os sobrenadantes foram descartados. Em seguida os precipitados foram ressuspendidos em 1,4 $\mathrm{mL}$ de Ácido Perclórico (PCA) 30\% e centrifugados a $14000 \mathrm{rpm}$ por $15 \mathrm{~min}$, a $4{ }^{\circ} \mathrm{C}$. Os sobrenadantes foram coletados e os precipitados novamente ressuspendidos em $1,4 \mathrm{~mL}$ de PCA $30 \%$ e centrifugados nas mesmas condições anteriores. Os respectivos sobrenadantes foram misturados, e esses contêm o amido a ser dosado.

Para dosagem do amido, alíquotas de $1 \mathrm{~mL}$ dos extratos foram adicionadas a $2 \mathrm{~mL}$ de antrona 0,2\% (diluída em ácido sulfúrico 95\%). Essas soluções foram agitadas e então aquecidas a $100{ }^{\circ} \mathrm{C}$ em banho seco, por três min. Após resfriar à temperatura ambiente, foi realizada a leitura da absorbância das amostras, em espectrofotômetro a $620 \mathrm{~nm}$. As absorbâncias foram anotadas e utilizadas para calcular a concentração de dextrose $(\mu \mathrm{g} / \mathrm{mL})$, através da equação de regressão linear $[$ Dextrose] $=f(A B S)$. Os valores foram multiplicados por 0,9 para obter a concentração de amido $(\mu \mathrm{g} / \mathrm{mL})$. A quantidade de amido nas amostras foi determinada a partir de curva padrão com concentrações conhecidas de glicose.

\subsection{Análise de Proteínas}

A extração das proteínas foi realizada de acordo com a metodologia de Natarajan et al. (2005), com modificações.

Amostras de $300 \mathrm{mg}$ das CE e das CNE foram maceradas em triplicatas, sendo adicionados $1,0 \mathrm{~mL}$ de tampão de extração Uréia/Tiouréia contendo $0,01 \mathrm{~g} \cdot \mathrm{mL}^{-1}$ Dithiothreitol (DTT), $8 \mu \mathrm{L} \cdot \mathrm{mL}^{-1}$ de Triton 100, $2 \mu \mathrm{L} \cdot \mathrm{mL}^{-1}$ de Pharmalyte, $20 \mu \mathrm{L} \cdot \mathrm{mL}^{-1}$ de PMSF, $5 \mu \mathrm{L} \cdot \mathrm{mL}^{-1}$ de Pepstatina $(1 \mathrm{mM})$ e $970 \mu \mathrm{L} \cdot \mathrm{mL}^{-1}$ de uréia/Tiouréia 
(Uréia 7M, Tiouréia 2M), completou-se o volume com água, adicionou-se Amberlite 150 NL para deionizar a solução e filtrou-se em membrana 0,22 $\mu \mathrm{m}$.

Após maceradas, as amostras foram agitadas por $5 \mathrm{~min}$ a temperatura ambiente, e incubadas por $1 \mathrm{~h}$ a $4^{\circ} \mathrm{C}$ e centrifugadas a $14000 \mathrm{rpm}$ por $10 \mathrm{~min}$, a $4^{\circ} \mathrm{C}$. O sobrenadante foi coletado e as proteínas totais foram quantificadas.

Para quantificação foi utilizado o 2D Quant Kit GE Healthcare ${ }^{\circledR}$, seguindo as indicações do fabricante. A leitura da absorbância foi realizada em aparelho de ELISA a $480 \mathrm{~nm}$.

Foi gerada uma curva padrão com soro de albumina bovina (BSA a $2 \mathrm{mg} / \mathrm{mL}$ ) em concentrações entre 0 e $50 \mu \mathrm{g}$ e esta foi utilizada para calcular a concentração de proteínas das amostras.

\subsection{Análise de Poliaminas (PAs)}

As PAs livres foram extraídas e analisadas em triplicata, seguindo a metodologia proposta por Silveira et al. (2004b).

As amostras de $300 \mathrm{mg}$ das CE e CNE foram maceradas com 1,4 mL PCA $5 \%(\mathrm{v} / \mathrm{v})$ e incubadas a $4{ }^{\circ} \mathrm{C}$ por uma $\mathrm{h}$, sendo então centrifugadas a $14000 \mathrm{rpm}$ por $20 \mathrm{~min}$, a $4{ }^{\circ} \mathrm{C}$. O sobrenadante foi então separado e o precipitado ressuspendido com 0,2 mL de PCA 5\% e novamente centrifugado nas condições anteriores. Os sobrenadantes somados foram utilizados para quantificar as PAs livres.

Após serem extraídas, as PAs foram dansiladas para possibilitar sua identificação. Para tanto, $40 \mu \mathrm{L}$ do extrato de PAs foi homogeneizado com $20 \mu \mathrm{L}$ de Diaminoheptano (DAH) $0.05 \mathrm{mM}$ (que foi utilizado como controle interno), $50 \mu \mathrm{L}$ de solução saturada de carbonato de sódio $\left(\mathrm{NaHCO}_{3}\right)$ e $100 \mu \mathrm{L}$ de solução Cloreto de Dansyl (5 mg. $\mathrm{mL}^{-1}$ de acetona). Esse homogenato foi incubado a $70{ }^{\circ} \mathrm{C}$, por $50 \mathrm{~min}$. O excesso de cloreto de dansil foi convertido em dansil-prolina pela adição de $25 \mu \mathrm{L}$ de solução de Prolina (100 mg. $\mathrm{mL}^{-1}$ de água) com posterior incubação por 30 min no escuro, à temperatura ambiente. Então as PAs foram particionadas com $200 \mu \mathrm{L}$ de tolueno. A fase orgânica, contendo as PAs, foi coletada, seca em jato de N2 e ressuspendida em $175 \mu \mathrm{L}$ de acetonitrila. 
A identificação e quantificação das PAs foi realizada em HPLC, com coluna C18 de fase reversa (Shimadzu Shim-pack CLC ODS), usando detector de fluorescência, ajustado com o comprimento de onda de excitação a $340 \mathrm{~nm}$ e emissão a $510 \mathrm{~nm}$. Foram injetados no aparelho $20 \mu \mathrm{L}$ de cada amostra dansilada.

Como fase móvel foram utilizados acetonitrila $10 \%$ em água, com pH de 3,5 ajustado com $\mathrm{HCl} 1 \mathrm{~N}$, como solvente $\mathrm{A}$, e acetonitrila absoluta, como solvente $\mathrm{B}$, sendo ambas as soluções submetidas a filtração prévia, em filtros de 0,2 $\mu \mathrm{m}$. $\mathrm{O}$ programa de eluição da fase móvel iniciou com 65\% de acetonitrila absoluta e foi gradativamente aumentado até $100 \%$, durante um tempo total de corrida de $34 \mathrm{~min}$, com fluxo de $1 \mathrm{~mL} \cdot \mathrm{min}^{-1}$, a $40^{\circ} \mathrm{C}$.

As áreas dos picos e tempos de retenção de cada PA das amostras foram avaliadas por comparação com concentrações conhecidas de Put, Spd e Spm.

\subsection{Análises Estatísticas}

Após adquirir os dados quantitativos de carboidratos, amido, proteínas e poliaminas, estes foram submetidos à análise estatística utilizando o programa SAEG ${ }^{\circledR}$. 


\section{RESULTADOS}

\subsection{Curva de Crescimento}

A determinação das curvas de crescimento foi obtida através de coletas em intervalos de quatro dias durante os 32 dias de duração do experimento de multiplicação celular (figura 4).

Foi observado que as CE apresentam crescimento significativamente superior aquele obtido para as CNE (figura 4). As curvas nos permitiram analisar que as CE passam pela fase de adaptação ao novo meio (fase Lag) muito rapidamente. Aos quatro dias de cultivo CE parecem iniciar a fase de crescimento exponencial (fase Log), já atingindo $256 \mathrm{mg}$, MF significativamente maior quando comparada às $200 \mathrm{mg}$ iniciais. As CE mostram um crescimento exponencial até o $24^{\circ}$ dia de cultivo, onde atingem sua MF máxima de $519 \mathrm{mg}$. A partir desse momento a MF das colônias começa a diminuir, o que pode demonstrar a entrada das CE na fase estacionária, que possivelmente leva à inviabilidade da cultura (figura 4).

Figura 4 - Curvas de Crescimento elaboradas a partir da determinação de MF das colônias.

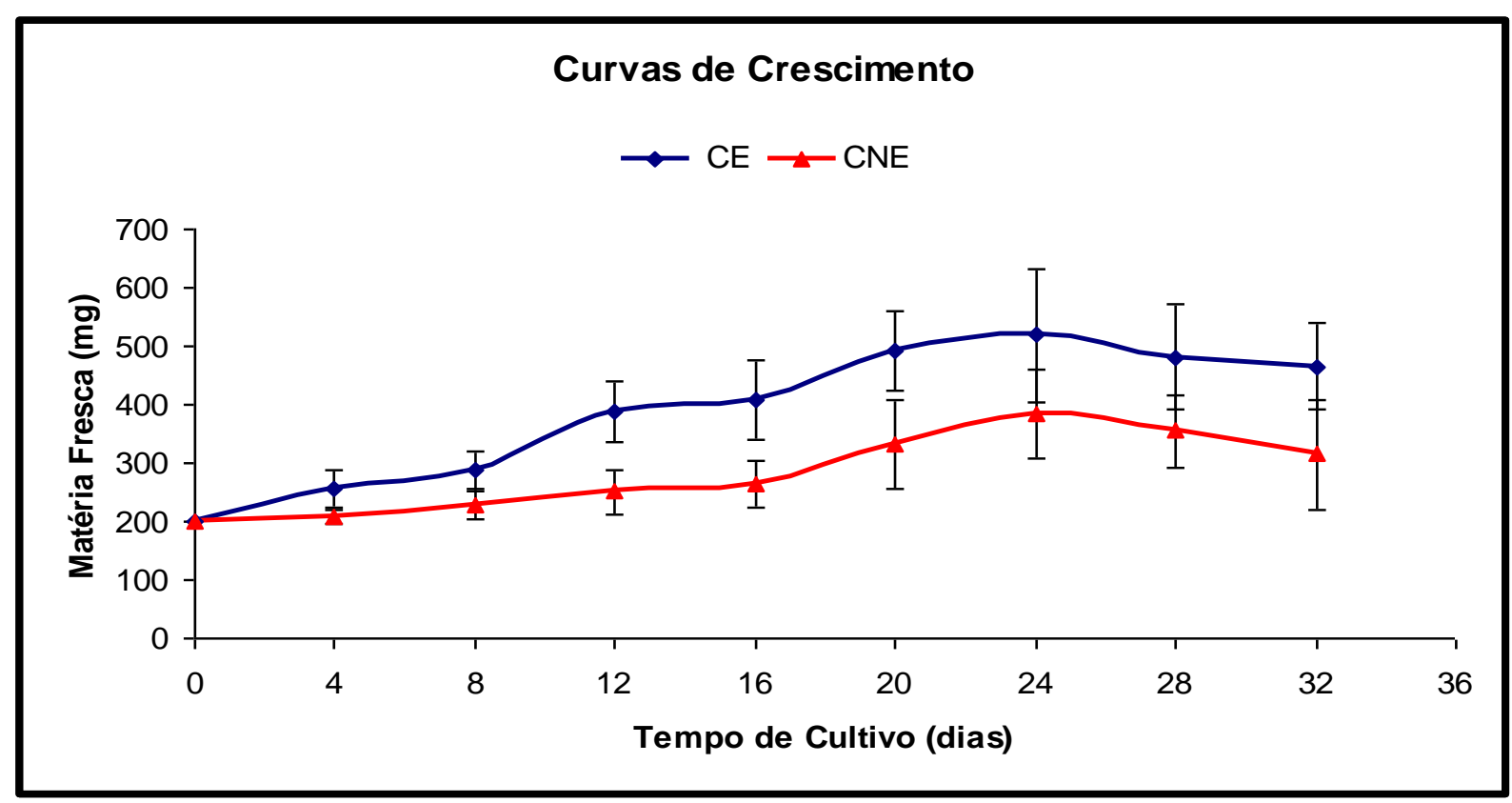

Culturas Embriogênicas (CE) E Culturas Não-Embriogênicas (CNE) ao longo de 32 dias de cultivo, n=3.. FONTE: Fim, 2012. 
Ao analisar a curva de crescimento das CNE foi observado que essas culturas demandam um tempo maior para se adaptar ao meio (fase Lag), parecendo iniciar crescimento progressivo (fase Log) somente a partir do $8^{\circ}$ dia de cultivo. Além disso, as CNE demonstram crescimento significativamente menor quando comparadas as $\mathrm{CE}$, tendo sua MF máxima de $384 \mathrm{mg}$, que também foi atingida aos 24 dias de cultivo. Assim como nas CE, a partir desse momento as CNE entram na fase estacionária e mostram uma diminuição em suas MF (figura 4).

\subsection{Carboidratos}

Os carboidratos analisados foram frutose, glicose e sacarose. Os resultados obtidos com a análise do conteúdo de frutose mostram uma quantidade muito maior desse carboidrato em CNE, quando comparadas com as CE (figura 5). Essa quantidade mostra-se até 10 vezes maior no $12^{\circ}$ e $32^{\circ}$ dias de cultivo. Porém a partir do $20^{\circ}$ dia de cultivo o conteúdo de frutose em CNE reduz, igualando-se com a quantidade presente em CE após 20 e 28 dias de incubação.

Figura 5 - Perfil de Frutose durante a multiplicação celular.

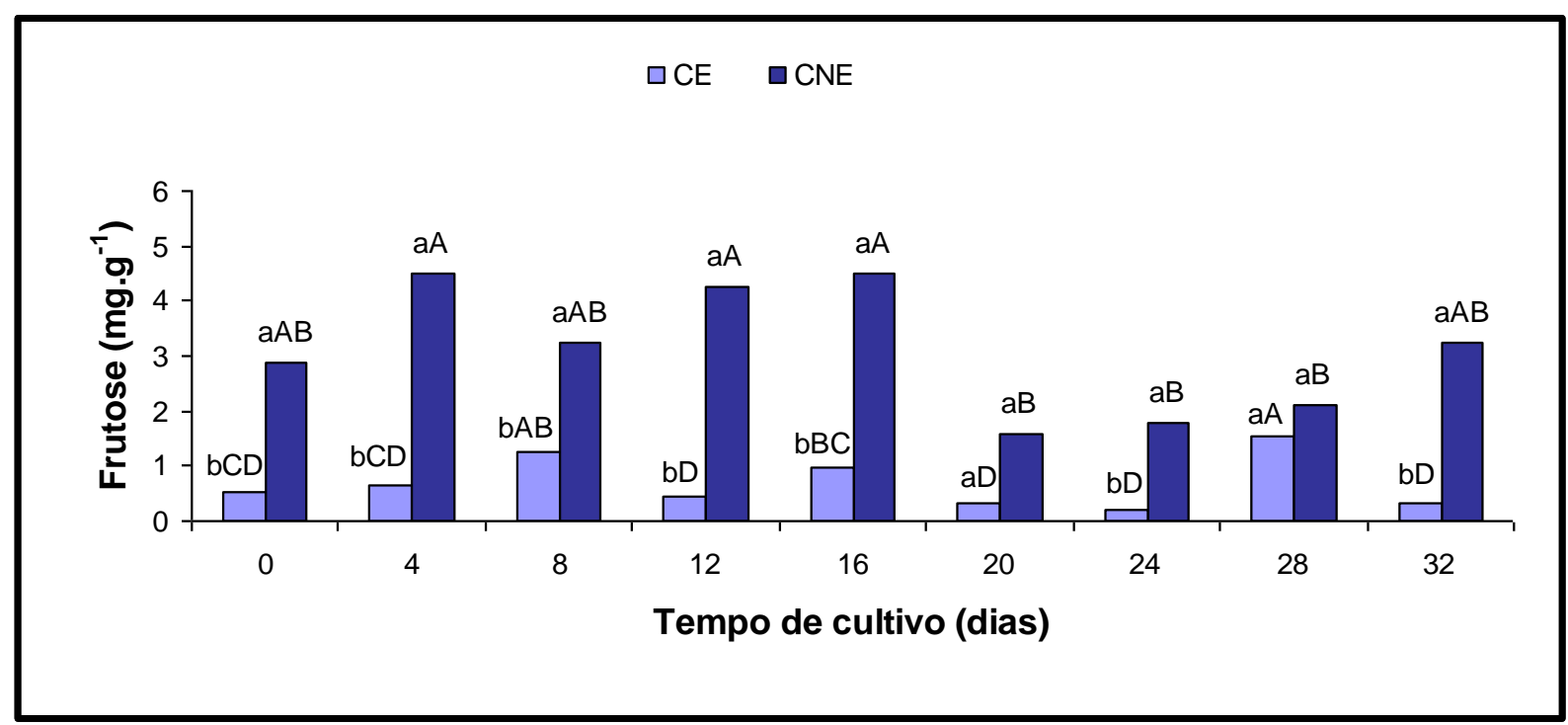

Culturas Embriogênicas (CE) e Não-Embriogênicas (CNE) acompanhadas ao longo de 32 dias de cultivo. As médias acompanhadas das mesmas letras não apresentam diferenças significativas de acordo com o teste SNK $(p<0.05)$. (CV $=25.9 \% ; n=3)$. Letras minúsculas denotam diferenças entre as culturas; letras maiúsculas denotam diferenças entre os dias de cultivo na mesma cultura.

FONTE: Fim, 2012. 
$\mathrm{Na}$ análise das CE nos diferentes dias de cultivo foi observado um aumento na quantidade de frutose nos dias 8,16 e 28, tendo quantidades entre 1,0 e $1,5 \mathrm{mg} \cdot \mathrm{g}^{-1}$ de MF. Nos demais dias de cultivo as quantidades foram igualmente baixas, estando entre 0,2 e $0,7 \mathrm{mg} \cdot \mathrm{g}^{-1}$ de MF. Frutose atinge sua maior quantidade em CE no $28^{\circ}$ dia de cultivo (1,5 mg. ${ }^{-1}$ de MF) (figura 5).

Já nas CNE o conteúdo de frutose é alto no início do cultivo, do $4^{\circ}$ ao $16^{\circ}$ dias, estando entre 3,2 e $4,5 \mathrm{mg}^{-1}$ de MF. Do $20^{\circ}$ ao $28^{\circ}$ dias de cultivo, a quantidade de frutose apresenta uma ligeira redução, com valores entre 1,6 e $2,9 \mathrm{mg} \cdot \mathrm{g}^{-1}$ de MF. No $32^{\circ}$ dia de cultivo a quantidade de frutose volta a subir (figura 5).

A análise do conteúdo de glicose na multiplicação celular permitiu observar que a quantidade de glicose também é consideravelmente maior nas CNE, em todo experimento, alcançando um valor 12 vezes maior aos 24 dias de cultivo (figura 6).

Figura 6 - Perfil de Glicose durante a multiplicação celular.

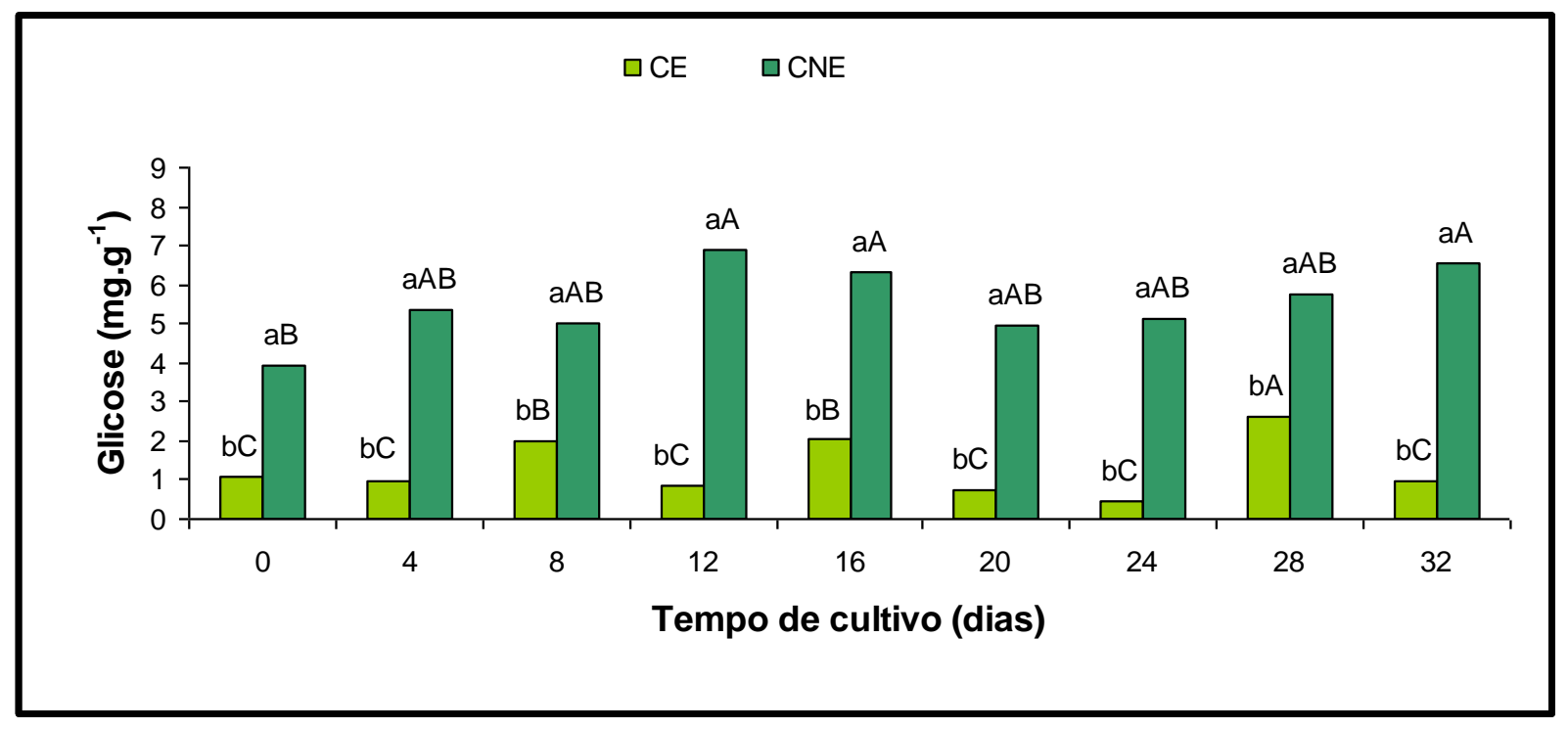

Culturas Embriogênicas (CE) e Não- Embriogênicas (CNE) acompanhadas ao longo de 32 dias de cultivo. As médias acompanhadas das mesmas letras não apresentam diferenças significativas de acordo com o teste SNK $(p<0.05)$. ( $C V=18.1 \% ; n=3)$. Letras minúsculas denotam diferenças entre as culturas; letras maiúsculas denotam diferenças entre os dias de cultivo na mesma cultura.

FONTE: Fim, 2012.

Nas CE a quantidade de glicose apresenta alternância entre queda e acúmulo. Nos quatro primeiros dias de incubação, a quantidade de glicose é muito baixa $\left(1,0 \mathrm{mg} \cdot \mathrm{g}^{-1}\right.$ de MF) e essa quantidade se repete estatisticamente aos 12,20 , 
24 e 32 dias. Nas coletas realizadas aos 8, 16 e 28 dias de incubação, a quantidade de glicose aumentou, obtendo seu valor máximo aos 28 dias de cultivo, com 2,6 $\mathrm{mg} \cdot \mathrm{g}^{-1}$ de MF (figura 6).

Nas CNE há pouca variação estatística no conteúdo de glicose entre os diferentes dias de cultivo, tendo a sua quantidade variando entre 3,9 e 6,9 mg.g ${ }^{-1}$ de MF. As maiores quantidades foram encontradas nos dias 12, 16 e 32, estando entre 6,3 e $6,9 \mathrm{mg} \cdot \mathrm{g}^{-1}$ de MF (figura 6).

Com a análise do conteúdo de sacarose durante a multiplicação celular, foi observado que esta é encontrada em maior quantidade nas CE nos quatro primeiros dias de cultivo, a partir do qual ao mesmo tempo em que a sacarose aumenta nas CNE, reduz nas CE. Dessa forma as quantidades se igualam entre 8 e 16 dias de incubação, sendo maiores nas CNE entre os dias 20 e 28. As quantidades voltam a se igualar aos 32 dias de cultivo (figura 7).

Figura 7 - Perfil de Sacarose durante a multiplicação celular.

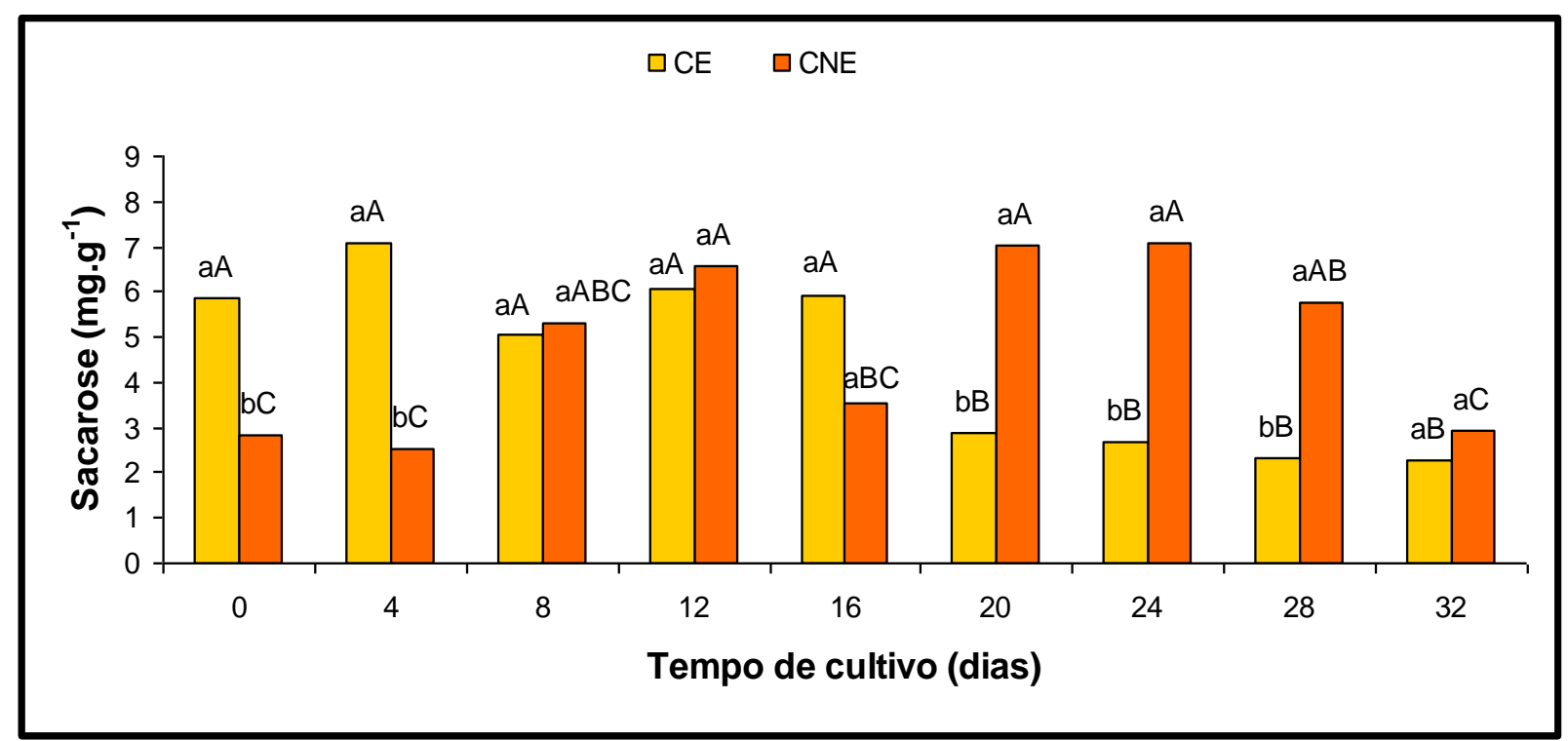

Culturas Embriogênicas (CE) e Não-Embriogênicas (CNE) acompanhadas ao longo de 32 dias de cultivo. As médias acompanhadas das mesmas letras não apresentam diferenças significativas de acordo com o teste SNK $(p<0.05)$. $(\mathrm{CV}=20.8 \% ; \mathrm{n}=3)$. Letras minúsculas denotam diferenças entre as culturas; letras maiúsculas denotam diferenças entre os dias de cultivo na mesma cultura.

FONTE: Fim, 2012.

No estudo das CE entre os dias de cultivo foi visto que o conteúdo de sacarose é estatisticamente superior até o $16^{\circ}$ dia de incubação, estando entre 5,1 e 
$7,1 \mathrm{mg} \cdot \mathrm{g}^{-1}$ de MF. No $20^{\circ}$ dia de cultivo essa quantidade declina consideravelmente e se mantém estável até o final do experimento, estando entre 2,3 e 2,9 mg. $\mathrm{g}^{-1}$ de MF (figura 7).

Se observou que nas CNE, a sacarose ocorre em baixas concentrações durante os quatro primeiros dias de cultivo (entre 2,5 e 2,8 $\mathrm{mg} \cdot \mathrm{g}^{-1}$ de MF), apresentando progressivo aumento a partir do $8^{\circ}$ dia. No $16^{\circ}$ dia essa quantidade é reduzida, atingindo $3,5 \mathrm{mg} \cdot \mathrm{g}^{-1}$ de $\mathrm{MF}$, seguido de novo aumento nos dias posteriores, apresentando conteúdo máximo aos 24 dias de cultivo $\left(7,1 \mathrm{mg} \cdot \mathrm{g}^{-1} \mathrm{de}\right.$ MF). A partir do $28^{\circ}$ dia a quantidade de sacarose nas CNE sofre novo declínio, voltando a se igualar aos primeiros dias de cultivo (figura 7 ).

Ao compararmos as concentrações dos três açúcares analisados durante todo o período de incubação foi possível observar que em CE a sacarose é o carboidrato claramente predominante e a quantidade desse carboidrato começa a reduzir no momento em que esses calos atingem o período de subcultivo (transferência de meio de cultura) o que acontece aproximadamente aos 21 dias de cultivo (figura 7). Glicose e frutose em CE têm quantidades consideravelmente inferiores às observadas em CNE e não mostram variações significativas entre as coletas, mantendo ciclos de pequenos aumento e/ou queda ao longo do período de incubação (figuras 5 e 6 ).

É possível observar também que frutose e glicose mantêm uma uniformidade de variação nas $\mathrm{CE}$, tendo momentos de queda e acúmulo aproximadamente juntos, o que não ocorre com a sacarose (figuras 5, 6 e 7). Além disso, o maior conteúdo de frutose e glicose nesse tipo celular é encontrado aos 28 dias de cultivo $(1,5 \mathrm{e}$ 2,6 $\mathrm{mg} \cdot \mathrm{g}^{-1}$ de MF, respectivamente), ao contrário da sacarose que tem aos 28 dias seu menor conteúdo (2,3 mg.g ${ }^{-1}$ de MF) (figuras 5, 6 e 7).

Já nas CNE não há predominância geral de um carboidrato, eles se alternam em períodos em que um está em maior quantidade comparativamente ao outro (figuras 5, 6 e 7). Foi possível observar também que apesar dos momentos de maiores e menores concentrações de glicose, frutose e sacarose não serem convergentes como nas $\mathrm{CE}$, frutose e glicose apresentam certa uniformidade de variação, tendo momentos de declínio e acúmulo aproximadamente juntos, como nas CE (figuras 5 e 6). 


\subsection{Amido}

Através da quantificação de amido foi observado que seu conteúdo é variável nos diferentes dias de coleta, com maior quantidade em CNE, principalmente no início do cultivo. Nos oito primeiros dias de cultivo e nos dias 16 e 28 a quantidade de amido é maior em CNE. Nos dias 12, 20, 24 e 32 as quantidades entre CE e CNE se igualam (figura 8).

Figura 8 - Perfil de Amido durante a multiplicação celular.

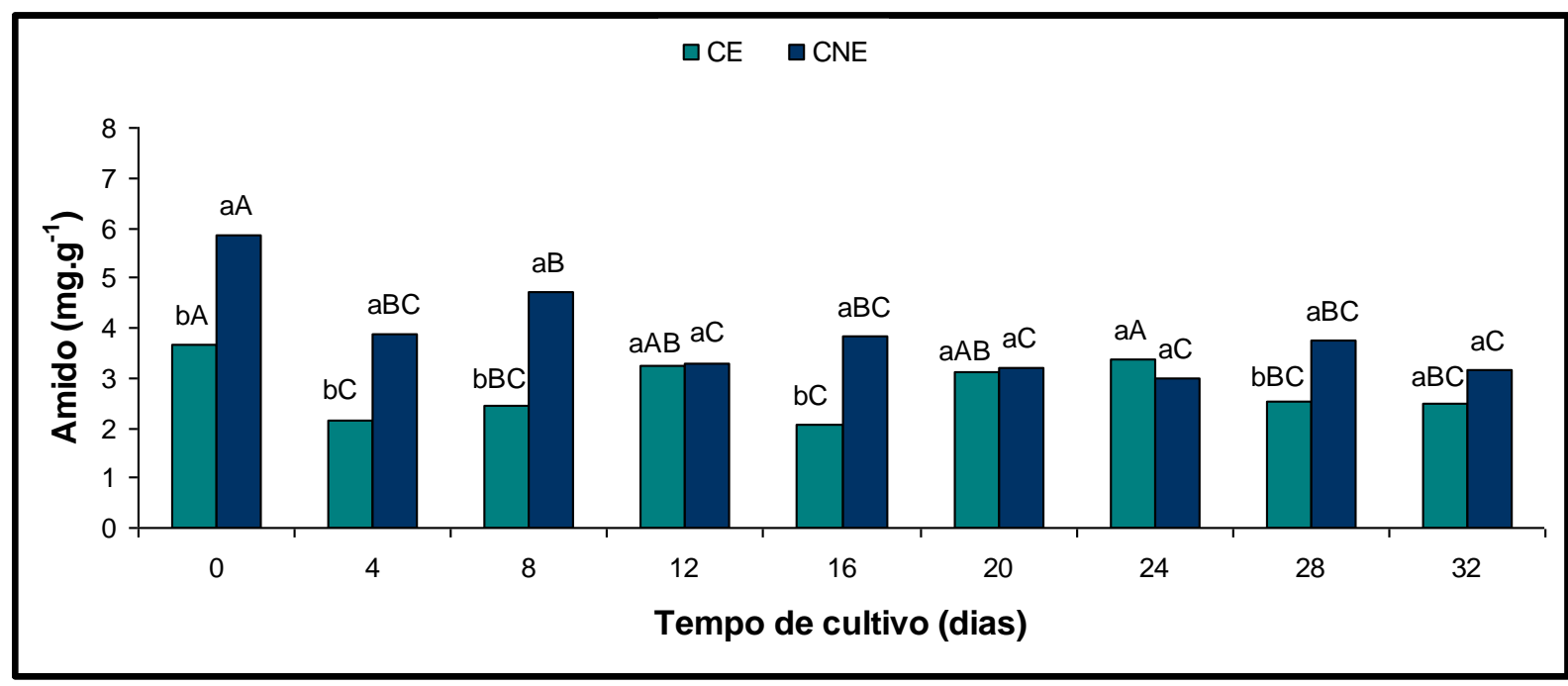

Culturas Embriogênicas (CE) e Não-Embriogênicas (CNE) acompanhadas ao longo de 32 dias de cultivo. As médias acompanhadas das mesmas letras não apresentam diferenças significativas de acordo com o teste SNK $(p<0.05)$. (CV = 13.2\%; $n=3)$. Letras minúsculas denotam diferenças entre as culturas; letras maiúsculas denotam diferenças entre os dias de cultivo na mesma cultura.

FONTE: Fim, 2012.

Em CE, entre as diferentes coletas realizadas durante o acompanhamento, não foram observadas grandes variações no conteúdo de amido. O dia da inoculação (dia 0) e os dias 12, 20 e 24 são estatisticamente iguais, com quantidades variando entre 3,1 e $3,7 \mathrm{mg} \cdot \mathrm{g}^{-1}$ de MF. Já os dias 4, 8, 16, 28, 32, têm quantidades de amido mais baixas e também se mostram estatisticamente iguais com valores entre 2,1 e $2,5 \mathrm{mg} \cdot \mathrm{g}^{-1}$ (figura 8 ).

Em CNE o dia de inoculação (dia 0) apresenta maior diferença estatística na quantidade de amido, quando comparado às demais datas de coleta, tendo $5,9 \mathrm{mg} \cdot \mathrm{g}^{-1}$ de MF. Entre os dias 4 e 12 foi observado uma variação no conteúdo de 
amido, que sofre acréscimo e queda, tendo quantidades entre 3,3 e 4,7 mg.g ${ }^{-1}$ de MF. A partir do $12^{\circ}$ dia, a quantidade é estatisticamente igual, com valores entre 3,0 e $3,8 \mathrm{mg} \cdot \mathrm{g}^{-1}$ (figura 8).

\subsection{Proteínas}

Com a análise quantitativa de proteínas totais nas CE e CNE durante o período de multiplicação celular foi possível observar que há quantidade protéica significativamente maior em CE, em todas as datas de coleta, sendo essa quantidade até quatro vezes superior, no $12^{\circ}$ dia de cultivo (figura 9), comparativamente com CNE.

Figura 9 - Perfil de Proteínas Totais durante a multiplicação celular.

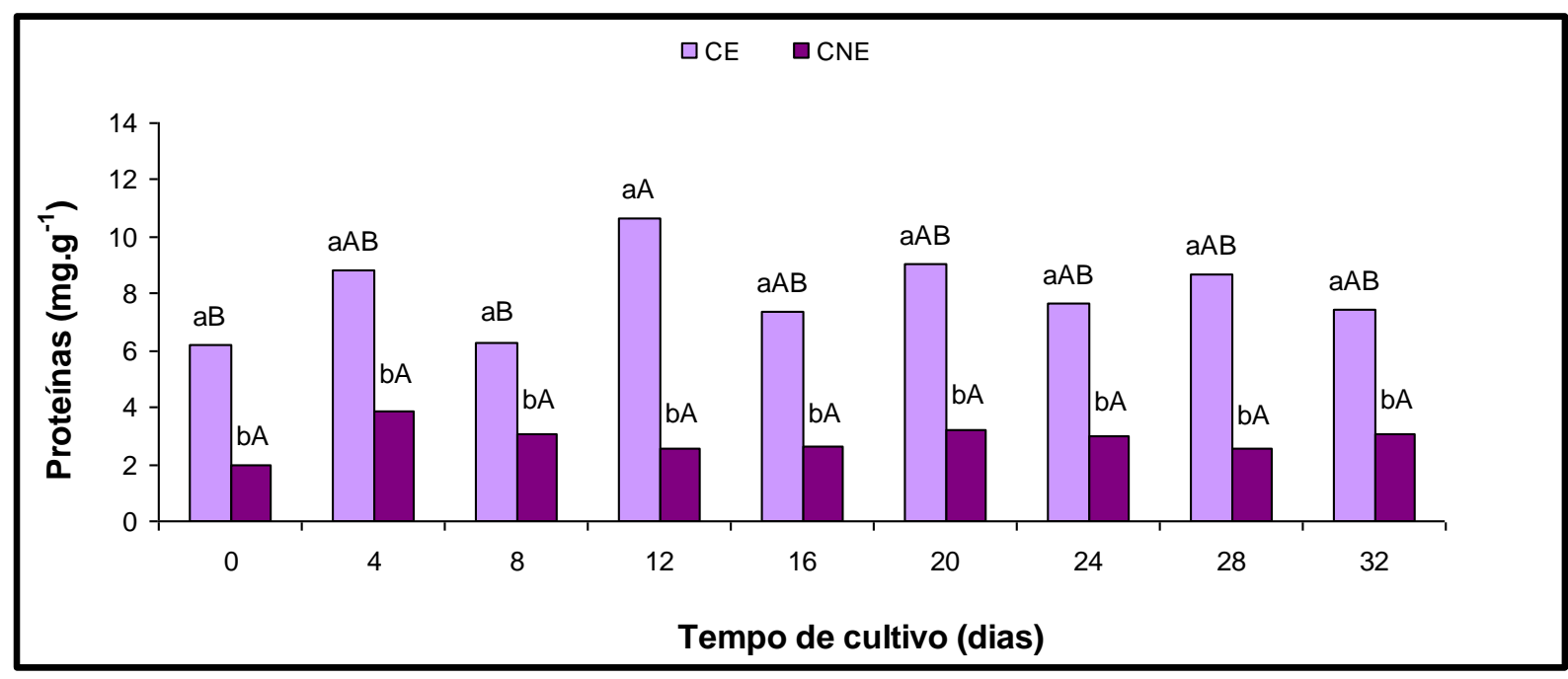

Culturas Embriogênicas (CE) e Não-Embriogênicas (CNE) acompanhadas ao longo de 32 dias de cultivo. As médias acompanhadas das mesmas letras não apresentam diferenças significativas de acordo com o teste SNK $(p<0.05)$. (CV = 19.7\%; $n=3)$. Letras minúsculas denotam diferenças entre as culturas; letras maiúsculas denotam diferenças entre os dias de cultivo na mesma cultura.

FONTE: Fim, 2012.

A análise das CE possibilitou observar pouca variação entre as datas de coleta. $O$ maior conteúdo de proteínas foi atingido no $12^{\circ}$ dia de cultivo $\left(10,7 \mathrm{mg} \cdot \mathrm{g}^{-1}\right.$ de MF), estando os dias 4, 20 e 28 muito próximos a este valor (entre 8,7 e $9,1 \mathrm{mg} \cdot \mathrm{g}^{-1}$ de MF). Já a menor quantidade proteica foi encontrada no início do cultivo 
e no $8^{\circ}$ dia $\left(6,2 \mathrm{mg} \cdot \mathrm{g}^{-1}\right.$ de MF), tendo os dias 16, 24 e 32 quantidades próximas a esses (entre 7,3 e 7,7 mg.g ${ }^{-1}$ de MF) (figura 9).

Por outro lado, em CNE pode-se observar que não ocorre diferença estatística significativa entre as diferentes datas de coleta, com valores de proteínas entre 2,0 e 3,8 mg.g ${ }^{-1}$ de MF (no dia zero e quatro, respectivamente) (figura 9).

\subsection{Poliaminas (PAs)}

A análise de PAs permitiu o estudo dos conteúdos de Put, Spd e Spm em culturas CE e CNE durante os 32 dias de acompanhamento da multiplicação celular.

O estudo de Put possibilitou observar que em CNE existe uma quantidade muito maior dessa PA, quando comparadas a CE, atingindo um conteúdo sete vezes maior no $20^{\circ}$ dia de cultivo (figura 10 ).

Figura 10 - Perfil de Putrescina durante a multiplicação celular.

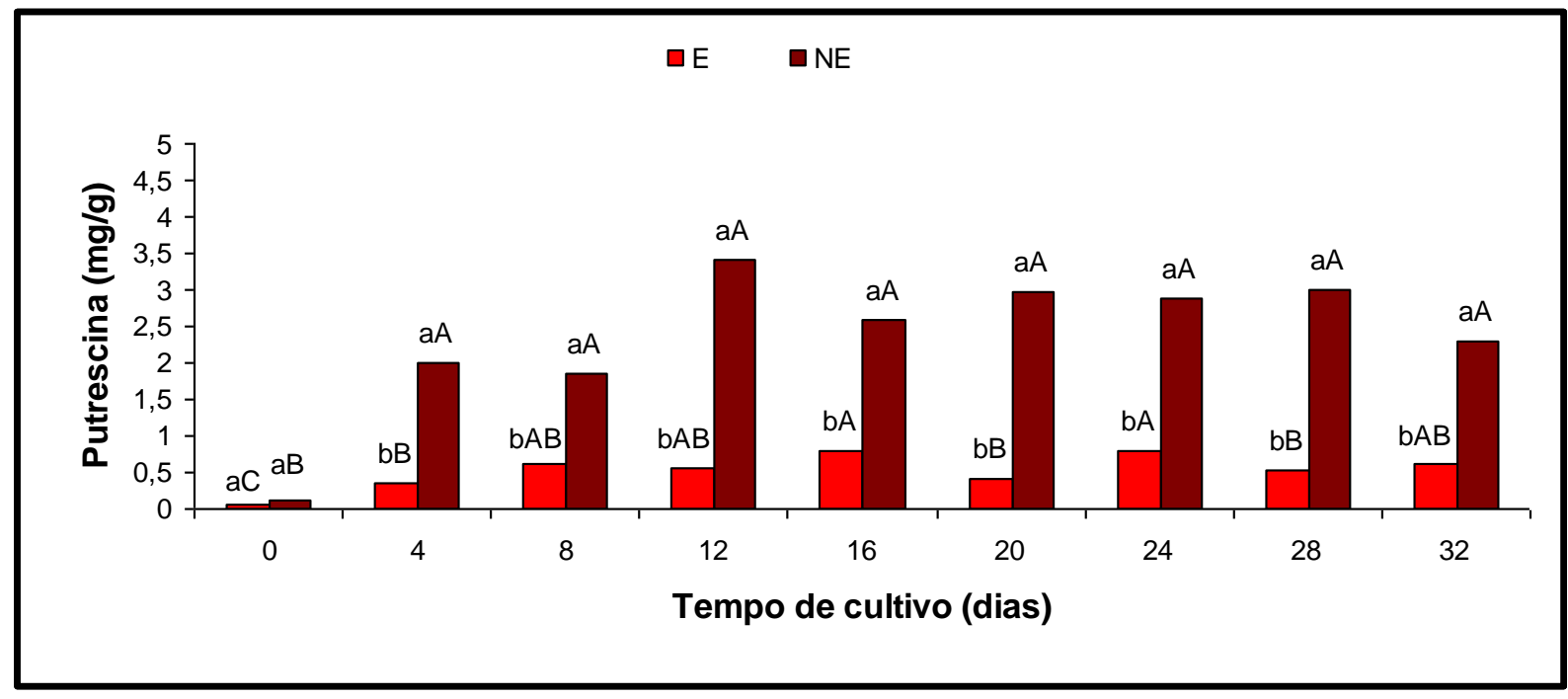

Culturas Embriogênicas (CE) e Não-Embriogênicas (CNE) acompanhadas ao longo de 32 dias de cultivo. As médias acompanhadas das mesmas letras não apresentam diferenças significativas de acordo com o teste SNK $(p<0.05)$. (CV = 30.1\%; $n=3)$. Letras minúsculas denotam diferenças entre as culturas; letras maiúsculas denotam diferenças entre os dias de cultivo na mesma cultura.

FONTE: Fim, 2012.

Sobre o conteúdo de Put nas CE foi observado que ocorre um acréscimo progressivo em sua quantidade até $016^{\circ}$ dia de cultivo, subindo de 0,05 para 
$0,79 \mathrm{mg} \cdot \mathrm{g}^{-1}$ de MF. A partir do $20^{\circ}$ dia de cultivo a Put apresentou variações subsequentes, ocorrendo quedas e acúmulos de sua quantidade até o final do acompanhamento, com valores entre 0,41 e $0,8 \mathrm{mg} \cdot \mathrm{g}^{-1}$ de MF (figura 10).

As CNE demonstram uma uniformidade no conteúdo de Put. Esse conteúdo é estatisticamente igual do $4^{\circ}$ ao $32^{\circ}$ dia de cultivo, com quantidades entre 1,9 e 3,4 $\mathrm{mg} \cdot \mathrm{g}^{-1}$ de MF. Apenas no dia de inoculação (dia 0 ) essa quantidade sai do padrão, apresentando quantidade de $0,12 \mathrm{mg} \cdot \mathrm{g}^{-1}$ de $\mathrm{MF}$, que é próxima a quantidade encontrada nas CE nessa data (figura 10).

Ao se analisar o conteúdo de Spd em CE e CNE foi observado que existem poucas diferenças em suas quantidades. Diferenças significativas só foram vistas nos dias 12, onde CE possuem mais Spd, e 20, onde CNE tem maior quantidade dessa PA (figura 11).

Figura 11 - Perfil de Espermidina durante a multiplicação celular.

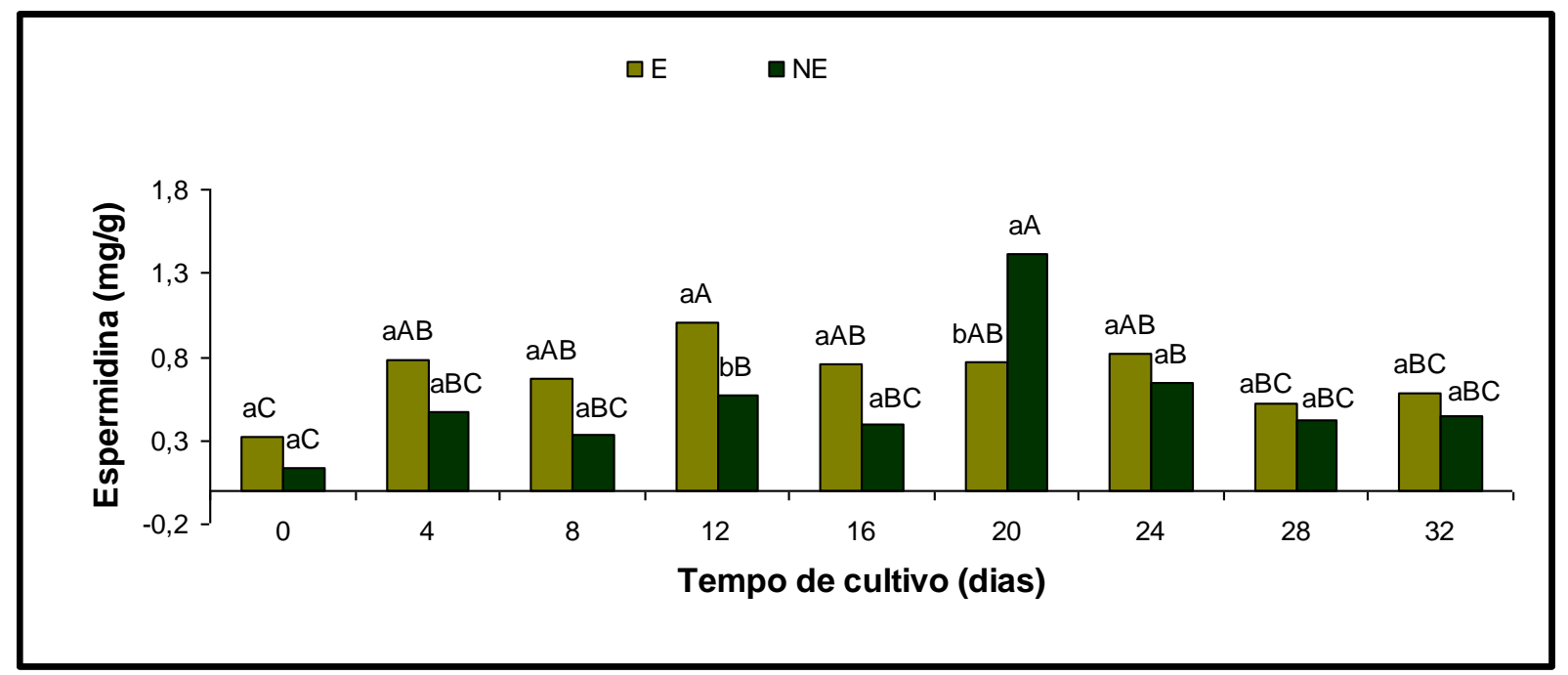

Culturas Embriogênicas (CE) e Não-Embriogênicas (CNE) acompanhadas ao longo de 32 dias de cultivo. As médias acompanhadas das mesmas letras não apresentam diferenças significativas de acordo com o teste SNK $(p<0.05)$. $(C V=22.4 \% ; n=3)$. Letras minúsculas denotam diferenças entre as culturas; letras maiúsculas denotam diferenças entre os dias de cultivo na mesma cultura.

FONTE: Fim, 2012.

No estudo das CE nos diferentes dias de cultivo foram observados pequenos acréscimos e decréscimos cíclicos de Spd, porém esses não mostram grandes diferenças estatísticas. A maior quantidade é encontrada no $12^{\circ}$ dia de cultivo e é igual a $1,0 \mathrm{mg} \cdot \mathrm{g}^{-1}$ de MF. $\mathrm{O}$ início do cultivo (0 dias) apresenta o menor conteúdo de 
Spd, que é de $0,32 \mathrm{mg} \cdot \mathrm{g}^{-1}$ de MF. As demais datas de coleta têm quantidades entre 0,52 e $0,82 \mathrm{mg} \cdot \mathrm{g}^{-1}$ de MF (figura 11).

Na análise de Spd nas CNE foram observados ciclos bem parecidos com os encontrados nas $C E$, tendo pequenos acréscimos e decréscimos que não geram diferenças estatísticas consideráveis. Apenas o $20^{\circ}$ dia se destaca, tendo uma quantidade bem superior de Spd, quando comparado aos demais dias de cultivo, sendo igual a $1,41 \mathrm{mg} \cdot \mathrm{g}^{-1}$ de MF. O dia de inoculação (dia 0) apresenta a menor quantidade dessa PA $\left(0,14 \mathrm{mg} \cdot \mathrm{g}^{-1}\right.$ de MF). As demais coletas têm valores entre 0,34 e $0,64 \mathrm{mg} \cdot \mathrm{g}^{-1}$ de MF (figura 11).

O estudo do conteúdo de Spm em CE e CNE aponta uma maior quantidade dessa PA em CNE no início do cultivo (0 dias) e aos 20 dias, momento em que o conteúdo de Spm em CNE é 12 vezes maior que em CE. Nas demais datas do acompanhamento a quantidade de Spm em CE e CNE é estatisticamente igual (figura 12).

Figura 12 - Perfil de Espermina durante a multiplicação celular.

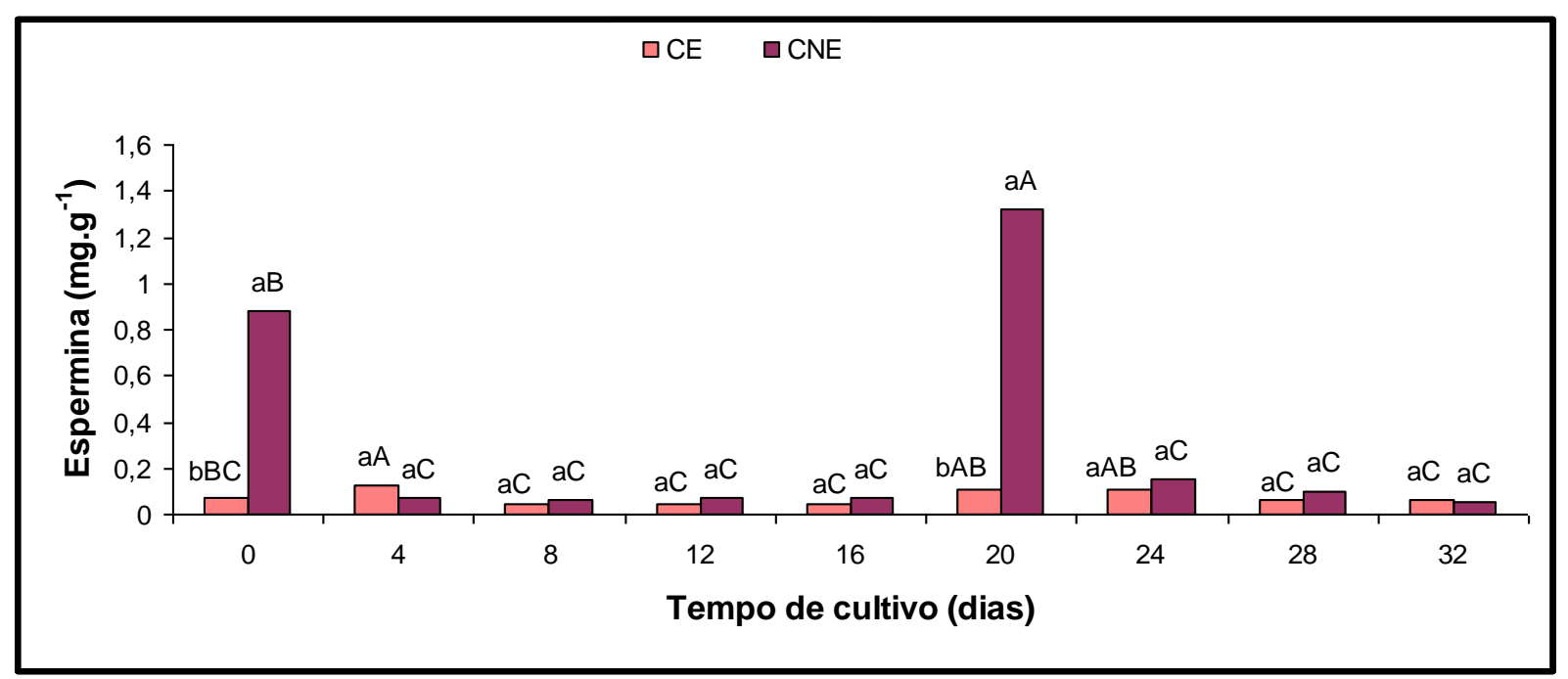

Culturas Embriogênicas (CE) e Não-Embriogênicas (CNE) acompanhadas ao longo de 32 dias de cultivo. As médias acompanhadas das mesmas letras não apresentam diferenças significativas de acordo com o teste SNK $(p<0.05)$. $(\mathrm{CV}=35.6 \% ; \mathrm{n}=3)$. Letras minúsculas denotam diferenças entre as culturas; letras maiúsculas denotam diferenças entre os dias de cultivo na mesma cultura.

FONTE: Fim, 2012.

Ao analisar o conteúdo de Spm em CE foi observado que sua quantidade é um pouco maior na inoculação (0 dias) e nos dias 4, 20 e 24, apresentando valores 
entre 0,08 e $0,12 \mathrm{mg} \cdot \mathrm{g}^{-1}$ de MF. Nas demais datas do acompanhamento, essa PA tem valores mais baixos, entre 0,05 e $0,06 \mathrm{mg}^{-1} \mathrm{~g}^{-1}$ (figura 12).

Já a análise de Spm em CNE mostra valores altos no início do cultivo (dia 0), sendo de 0,8 mg. $\mathrm{g}^{-1}$ de MF, e aos 20 dias, de 1,32 mg. ${ }^{-1}$ de MF. Os demais dias do experimento possuem valores igualmente baixos de Spm, estando entre 0,05 e $0,15 \mathrm{mg} \cdot \mathrm{g}^{-1}$ de MF (figura 12).

A comparação dos conteúdos das diferentes PAs em CE, possibilitou observar que Spm é a PA que possui quantidades inferiores nessas culturas, tendo valores entre 0,05 e $0,12 \mathrm{mg} \cdot \mathrm{g}^{-1}$ de MF (figura 12). Put e Spd possuem valores maiores, alcançando 0,8 e 1,0 mg.g ${ }^{-1}$ de MF, respectivamente (figuras 10 e 11). Mesmo estando em maiores quantidades essas PAs apresentam valores muito inferiores às médias encontradas nas CNE.

A análise dos conteúdos das diferentes PAs nas CNE aponta a Put como a PA predominante dessas culturas, tendo valores que alcançam $3,4 \mathrm{mg} \cdot \mathrm{g}^{-1}$ de $\mathrm{MF}$ (figura 10). Spd e Spm tem quantidades baixas que não ultrapassam 1,41 e $1,32 \mathrm{mg} \cdot \mathrm{g}^{-1}$ de MF, respectivamente (figuras 11 e 12).

Os dados adquiridos com a análise das PAs totais confirmam a análise feita entre as PAs estudadas, mostrando que as PAs estão em maiores concentrações nas CNE. Apenas no início do cultivo (dia 0) e aos oito dias os valores de PAs totais se igualam estatisticamente em CE e CNE (figura 13).

Nas CE as PAs totais mostram quantidades sem diferenças significativas durante o cultivo, tendo valores entre 1,1 e $1,7 \mathrm{mg}^{-1} \mathrm{~g}^{-1}$ de MF. Apenas no momento da inoculação (dia 0) o valor se difere das outras datas, sendo de $0,5 \mathrm{mg}^{-1} \mathrm{~g}^{-1} \mathrm{de} \mathrm{MF}$ (figura 13).

O estudo das PAs totais nas CNE mostra um pico na quantidade de PAs aos 20 dias de cultivo, com valor igual a $5,7 \mathrm{mg} \cdot \mathrm{g}^{-1}$ de MF. O momento de inoculação (dia 0) mostrou quantidade inferior às demais datas de coleta, tendo valor de $1,1 \mathrm{mg} \cdot \mathrm{g}^{-1}$ de MF. No restante do experimento as PAs totais em CNE tem valores estatisticamente iguais, estando entre 2,3 e 4,0 mg.g ${ }^{-1}$ de MF (figura 13). 
Figura 13 - Perfil de Poliaminas Totais durante a multiplicação celular.

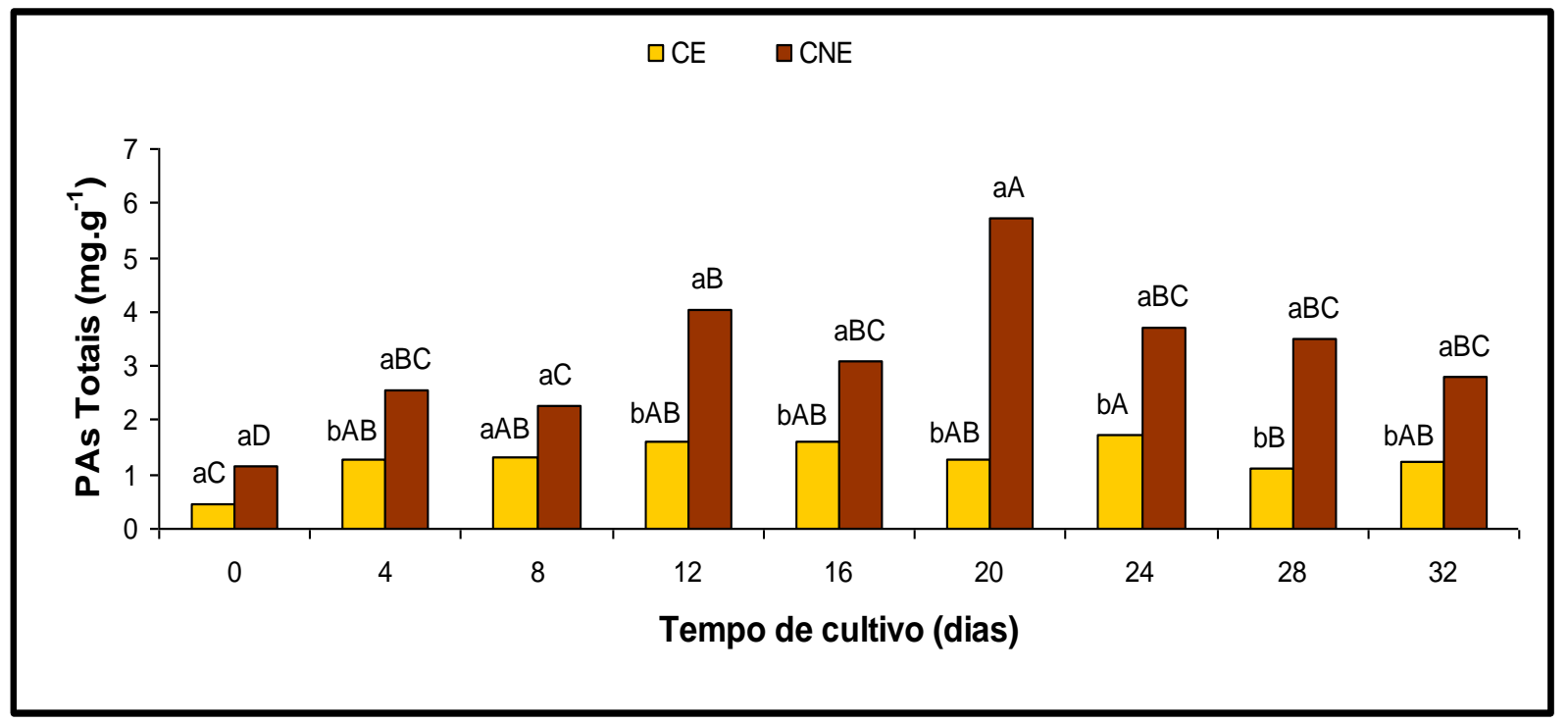

Culturas Embriogênicas (CE) e Não-Embriogênicas (CNE) acompanhadas ao longo de 32 dias de cultivo. As médias acompanhadas das mesmas letras não apresentam diferenças significativas de acordo com o teste SNK $(p<0.05)$. (CV = 19.7\%; $n=3)$. Letras minúsculas denotam diferenças entre as culturas; letras maiúsculas denotam diferenças entre os dias de cultivo na mesma cultura.

FONTE: Fim, 2012.

A razão entre PAs se estabelece a partir da divisão do conteúdo de Put pela soma dos conteúdos de Spd e Spm [Razão PAs= Put/(Spd+Spm)].

A partir da analise dessa razão foi possível observar que seus níveis são muito superiores em CNE, quando comparadas a CE, tendo valores até nove vezes maiores nessas culturas, nos dias 4 e 12. As quantidades dessa razão só se igualam entre CNE e CE no inicio do cultivo (dia 0) e no $20^{\circ}$ dia (figura14).

Durante o cultivo, nas CE foi observado que a razão entre PAs sofre aumento progressivo até o $8^{\circ}$ dia, então esta razão entra em ciclos de diminuição e aumento sucessivos que duram até $024^{\circ}$ dia, a partir do qual se estabiliza, até o final do cultivo. Os dias 4,12 e 20 têm menores valores, estando entre 0,4 e 0,6. Os dias 8 , 16, 24, 28 e 32 têm valores maiores, estando entre 0,8 e 1,0 (figura 14).

Já a razão entre PAs nas CNE mostrou pouca variação significativa entre as datas de coleta. No dia da inoculação (dia 0 ) e no $20^{\circ}$ dia a razão é estatisticamente igual, com valores de 0,2 e 1,2, respectivamente. No restante do experimento essa possui valores superiores, estando entre 3,1 e 5,9 (figura 14). 
Figura 14 - Razão entre Poliaminas durante a multiplicação celular.

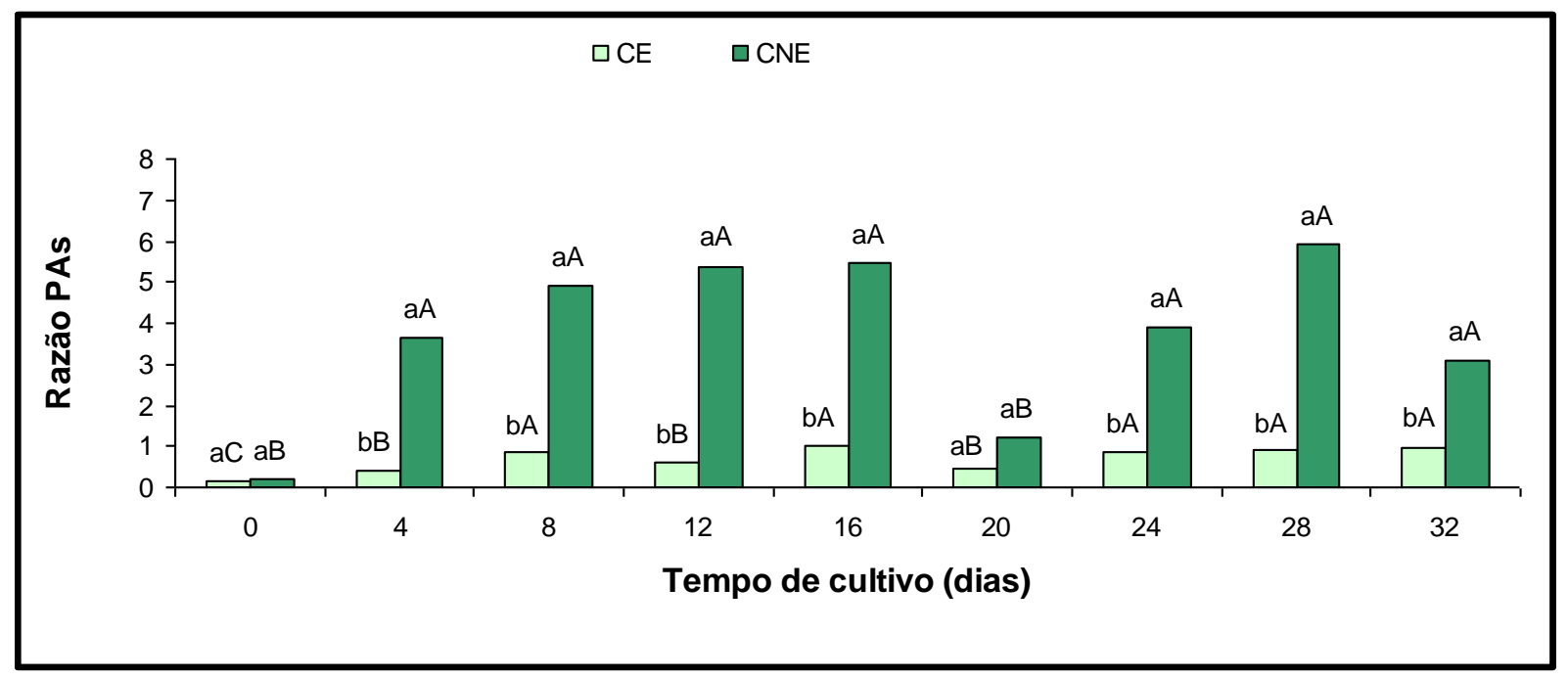

Culturas Embriogênicas (CE) e Não-Embriogênicas (CNE) acompanhadas ao longo de 32 dias de cultivo. As médias acompanhadas das mesmas letras não apresentam diferenças significativas de acordo com o teste SNK $(p<0.05)$. ( $C V=33.4 \% ; n=3)$. Letras minúsculas denotam diferenças entre as culturas; letras maiúsculas denotam diferenças entre os dias de cultivo na mesma cultura. Razão PAs= Put/(Spd+Spm).

FONTE: Fim, 2012.

Em resumo, podemos observar na tabela 1 que, ao se comparar os conteúdos totais médios das variáveis analisadas entre CE e CNE, durante a multiplicação celular, apenas o conteúdo de sacarose não apresentou diferenças estatísticas significativas. As demais variáveis apresentaram diferenças significativas (tabela 1), mostrando que CE e CNE são bioquimicamente diferentes.

Os conteúdos totais de proteínas e espermidina são maiores em CE. Já os conteúdos totais de amido, frutose, glicose, putrescina, espermina, PAs totais e razão entre PAs têm maiores valores nas CNE (tabela 1).

Tabela 1 - Quantidades médias dos parâmetros bioquímicos analisados.

\begin{tabular}{lcccccccccc}
\hline CALO & Amido & Frut & Glic & Sac & Prot & Put & Spd & Spm & PAs Totais & Razão PAs \\
\hline CE & $2,8 \mathrm{~b}$ & $0,7 \mathrm{~b}$ & $1,3 \mathrm{~b}$ & $4,5 \mathrm{a}$ & $8,0 \mathrm{a}$ & $0,5 \mathrm{~b}$ & $0,7 \mathrm{a}$ & $0,1 \mathrm{~b}$ & $1,3 \mathrm{~b}$ & $0,7 \mathrm{~b}$ \\
CNE & $3,9 \mathrm{a}$ & $3,1 \mathrm{a}$ & $5,5 \mathrm{a}$ & $4,9 \mathrm{a}$ & $2,9 \mathrm{~b}$ & $2,4 \mathrm{a}$ & $0,5 \mathrm{~b}$ & $0,3 \mathrm{a}$ & $3,2 \mathrm{a}$ & $3,8 \mathrm{a}$ \\
\hline CV (\%) & 13,2 & 25,9 & 18,1 & 20,8 & 19,7 & 30,1 & 22,4 & 35,6 & 19,7 & 33,4 \\
\hline
\end{tabular}

Valores médios (em mg. $\mathrm{g}^{-1}$ de MF) dos conteúdos totais em culturas embriogênicas (CE) e não-embriogênicas $(\mathrm{CNE})$, seguidos de suas determinações estatísticas. As médias acompanhadas das mesmas letras não apresentam diferenças significativas de acordo com o teste SNK $(p<0.05)$. Letras minúsculas denotam diferenças entre as culturas. CV: coeficientes de variação. n: 27 para todas as variáveis. Frut= frutose; Glic= glicose; $\mathrm{Sac}=$ sacarose; Prot= proteínas; Put= putrescina; Spd= espermidina; $\mathrm{Spm}=$ espermina; PAs Totais= soma das concentrações de put, spd e spm; Razão de PAs=[Put/(Spd+Spm)].

FONTE: Fim, 2012 


\section{DISCUSSÃO}

\subsection{Curva de Crescimento}

Culturas CE e CNE de cana-de-açúcar da variedade SP80-3280 foram mantidas sob as mesmas condições de cultivo para que seu desenvolvimento durante a multiplicação celular pudesse ser acompanhado e comparado. Estas culturas foram inoculadas em meio MS suplementado com sacarose, phytagel e 2,4-D e foram mantidas durante 32 dias, em estufa do tipo BOD, no escuro, com temperatura de $25 \pm 1^{\circ} \mathrm{C}$. A cada quatro dias as CE e CNE tiveram sua MF determinada e esses valores foram utilizados para elaboração de cada curva de crescimento.

Com as curvas de crescimento das CE e CNE já estabelecidas (figura 4), foi observado que os dois tipos celulares apresentam uma dinâmica de crescimento típica para suspensões celulares de plantas, representada por uma curva sigmóide (George, 2008). A curva sigmóide apresentada por George (2008) é composta de fases Lag, onde as células estão se adaptando ao novo meio, fase exponencial ou Log, onde o crescimento celular está em ascensão, fase linear, onde o crescimento celular se estabiliza, e fase estacionária, onde o crescimento celular diminui e as culturas podem acabar se tornando inviáveis.

Contudo, através da análise de matéria fresca foi possível determinar que as CE crescem progressivamente do $4^{\circ}$ ao $24^{\circ}$ dias de cultivo e, a partir do $24^{\circ}$ dia, essas culturas têm seu crescimento reduzido (figura 4). Observamos também que CNE crescem progressivamente entre $\circ 8^{\circ}$ e $\circ 24^{\circ}$ dias, a partir deste momento essas culturas também demonstram decréscimo em seu crescimento (figura 4). Entretanto, para ambas as culturas não foi possível inferir exatamente a transição entre as diferentes fases de crescimento da curva sigmóide.

Essa dinâmica de crescimento através de uma curva sigmóide também foi observada em outras espécies, como em culturas de A. angustifolia (Silveira et al., 2006), O. catharinensis (Santa-Catarina et al., 2007), Glycine max (He et al., 2011) e Phoenix dactylifera L. (Sghaier et al., 2008), porém, em cada espécie as fases da curva de crescimento se dão em tempos diferentes. Essa variação temporal também 
se mostra dependente do meio em que as culturas são inoculadas e se estes meios são sólidos ou líquidos.

Em CE de soja (G. Max), He et al. (2011) afirmam que o momento em que as culturas iniciam a diminuição de sua MF parece representar a entrada das células em senescência. Com a observação de que CE e CNE parecem iniciar um decréscimo de crescimento ao mesmo tempo, aos 24 dias de cultivo, podemos inferir que esse decréscimo está relacionado com a limitação de nutrientes no meio de cultura e que, por tanto, essas culturas necessitam ser subcultivadas, ou seja, transferidas para novo meio de cultura.

George (2008) afirma que culturas regularmente subcultivadas no final da fase exponencial normalmente podem ser propagadas por um longo período, por isso este momento seria o mais indicado para a subcultura. Neste trabalho foram realizadas repicagens a cada 21 dias, aproximadamente, tempo que coincide com o final da fase exponencial.

Além de analisarmos a curva de crescimento para cada tipo celular (CE e CNE) em separado, fizemos a comparação entre o crescimento celular nessas culturas. Com esta comparação observamos que CNE crescem com valores inferiores às CE (figura 4), o que está de acordo com o trabalho de Nieves et al. (2003), onde o autor afirma que CE de cana-de-açúcar crescem rapidamente e de forma organizada, enquanto as CNE crescem mais lentamente e de forma desordenada. Estes autores explicam que essa diferença de crescimento pode ser relacionada a diferenças de metabolismo, pois CE demonstram maior atividade metabólica comparativamente às CNE.

Contudo, diferentemente dos dados aqui obtidos, no trabalho de Oropeza et al. (2001) com suspensões celulares de cana-de-açúcar, os autores observaram um maior crescimento celular em CNE, o que afirmaram ser devido a diferenças entre as culturas, pois $\mathrm{CE}$, se comparadas às $\mathrm{CNE}$, são mais compactas, demandando mais tempo para estabelecimento de células livres no meio. Podemos relacionar essa diferença entre os trabalhos com o fato de que calos que se desenvolvem em meio sólido não demandam tempo para estabelecer culturas livres, diferentemente de suspensões celulares. Contudo, após o estabelecimento das suspensões celulares, com células livres no meio, este retardo no crescimento tende a ser minimizado. 
Em geral tem sido observado que o comportamento celular, o momento em que as culturas se encontram em cada fase da curva de crescimento, o momento adequado para repicagem e o potencial embriogênico das culturas são diretamente relacionados ao genótipo de cada espécie e de cada cultivar de cana-de-açúcar (Opereza et al., 2001).

\subsection{Carboidratos}

A determinação de carboidratos nos permitiu estudar os conteúdos de frutose, glicose e sacarose em CE e CNE. Com os dados obtidos no presente trabalho observamos que a concentração de sacarose varia inversamente em CE e CNE (figura 7) e essa variação inversa gera uma média do conteúdo total de sacarose sem diferenças significativas entre as duas culturas (tabela 1). Pescador et al. (2008) mostram que a sacarose tem pouca variação no seu conteúdo durante o desenvolvimento da embriogênese somática em Acca sellowiana, o que é relacionado pelos autores à presença de sacarose no meio de cultivo.

Cangahuala-Inocente et al. (2009) sugerem que a disponibilidade de carboidratos no meio de cultura poderia aumentar os níveis internos de açúcares solúveis. Nos dados aqui obtidos foi observado que em CE a quantidade de sacarose é alta no início do cultivo e declina do $20^{\circ}$ dia em diante (figura 7 ). Este padrão indica que as CE podem estar utilizando a sacarose presente no meio de cultura já no início do cultivo, visando promover o seu crescimento celular, processo minimizado quando as CE entram na fase estacionária, a partir dos 20 dias de cultivo. Contrariamente, em CNE a quantidade de sacarose é inferior nos primeiros dias de cultivo (figura 7), pois essas culturas demandam mais tempo para se adaptar ao meio de cultivo (com maior tempo na fase Lag) podendo, possivelmente desta forma, requerer sacarose do meio tardiamente. Assim ocorre acréscimo de seu conteúdo somente a partir do $8^{\circ}$ dia de cultura.

Com a determinação dos conteúdos de frutose e glicose foi observado que, em geral, as concentrações destes carboidratos são superiores em CNE, quando comparada a CE (tabela 1). Blanc et al. (2002) afirmam que a queda na disponibilidade de carboidratos dentro das células poderia criar um sinal que 
reorienta os programas de desenvolvimento, podendo gerar células determinadas a embriogênese somática. Esses autores também observam valor reduzido das hexoses intracelulares em Hevea brasiliensis.

No presente trabalho foi observado também que em CE os conteúdos de frutose e glicose variam simultaneamente (figuras 5 e 6), o que é coerente com as análises realizadas em Acca sellowiana (Pescador et al., 2008), e em sementes de Pinus taeda (Pullman, Buchanan, 2008), onde essa correlação também foi encontradas no desenvolvimento do embrião. A relação entre os conteúdos de frutose e glicose aponta ligação estreita entre seus metabolismos.

Santos et al. (2010) citam que em CE de Taxus brevifolia a hidrólise de sacarose foi associada à disponibilidade de glicose e frutose, o que é coerente com os dados observados no presente trabalho, uma vez que o maior conteúdo destas hexoses, que ocorre aos 28 dias de cultivo, é o momento em que encontramos menor conteúdo de sacarose.

Elevados conteúdos de sacarose também foram observados em CE de Acca sellowiana (Pescador et al., 2008; Cangahuala-Inocente et al., 2009). Os autores relacionam um maior conteúdo de hexoses à promoção da divisão e a diferenciação celular, enquanto que quando sacarose foi o açúcar predominante, processos tais como o alongamento celular e o armazenamento de proteínas e carboidratos pareceram ser estimulados. Ao compararmos os conteúdos médios totais dos carboidratos analisados observamos que em CE o carboidrato predominante é a sacarose e, em CNE o predomínio é de glicose (tabela 1). Assim é possível inferir que as CNE estão se multiplicando e dividindo, sem ocorrer uma organização para armazenamento de reservas, e que as CE estão determinadas a desenvolver os embriões somáticos, se organizando para alocar reservas que usarão no desenvolvimento destes embriões.

Essa afirmativa é pautada também no fato de ter sido observado que o conteúdo de proteínas totais é significativamente maior em CE no presente trabalho, demonstrando um maior acúmulo de reservas. Sánchez-Romero et al. (2002) também observaram que embriões zigóticos possuem baixos conteúdos de frutose e glicose e relacionaram esse fato a possível utilização de hexoses para síntese de sacarose, que será necessária para maturação dos embriões. 
Krajñáková et al. (2009) afirmam ainda que a sacarose possui papel na sinalização e regulação da embriogênese somática. Além disso, Iraqi, Tremblay (2001) mostram que a sacarose pode atuar como fator de regulação da maturação de embriões somáticos através de sua ação como sinal para a síntese de proteínas de armazenamento.

Contudo, os presentes resultados obtidos para carboidratos são contrários aos observados por Nieves et al. (2003) para a variedade de cana-de-açúcar CP-5243, onde foram encontradas quantidades superiores de frutose e glicose em $\mathrm{CE}$, quando comparados a CNE. Os autores afirmam que altos níveis destes são devido a uma maior atividade das enzimas invertase ácida e neutra em CE dessa variedade. A atividade de invertase ácida e neutra suporta a hidrólise de sacarose na mobilização de reservas (Nieves et al., 2003), consequentemente encontraram valores de sacarose menores em CE. Dosagens dessas enzimas seriam necessárias para relacionarmos sua atividade com o conteúdo de carboidratos encontrado em nosso estudo.

Em M. arbórea, Martin et al. (2000) também encontraram maiores conteúdos de frutose e glicose e menores conteúdos de sacarose em CE ao comparar às CNE. Os autores, porém, relacionam a quantidade de sacarose à utilização desta para a formação de embriões somáticos in vitro. Contudo, Martin et al. (2000) observaram que no início do cultivo, quando as culturas ainda não desenvolviam embriões, o conteúdo de sacarose não apresentou diferenças significativas entre CE e CNE.

Como demonstrado por Pescador et al. (2008), o gradiente de carboidratos parece estar envolvido no controle morfogenético, influenciando na divisão celular e diferenciação, além de participar da regulação do ciclo celular. Lakshamanan et al. (2005) afirmam ainda que um conhecimento do metabolismo de sacarose, e consequentemente de sua relação com metabolismos de frutose e glicose, pode gerar bases sólidas de manipulação para melhoria de cultivares de cana-de-açúcar.

\subsection{Amido}

A análise do conteúdo de amido foi realizada a partir do precipitado restante da extração dos carboidratos solúveis, de cada tipo celular (CE e CNE). O conteúdo 
de amido em CE não apresentou variações significativas durante os 32 dias de cultivo. CNE apresentaram um conteúdo maior e mais variável no início da multiplicação celular, porém a partir do $12^{\circ}$ dia a concentração de amido é reduzida e se estabiliza, não apresentando diferenças significativas a partir desse momento (figura 8). Este padrão de variação indica que a utilização do amido no período inicial do cultivo em CNE pode estar relacionada com o seu maior tempo na fase lag, visando se adaptar ao novo meio de cultura e, por isso, utiliza suas reservas para manter seu metabolismo. He et al. (2011) afirmam que o amido parece ser uma reserva temporária de carbono, podendo ser usado a qualquer momento para biossíntese.

Foi observado ainda que o conteúdo total de amido é maior em CNE (tabela 1), o que podemos relacionar com o fato de CE serem metabolicamente mais ativas e, por isso, não formarem tantos carboidratos de reserva (amido) quanto as CNE. Pescador et al. (2008) demonstram que o amido é rapidamente metabolizado em tecidos embrionários, fornecendo energia para as intensas atividades mitóticas, por isso menores quantidades de amido são encontradas. Blanc et al. (2002) também demonstraram baixo conteúdo de amido em células embrionárias de Hevea brasiliensis.

Martin et al. (2000) e Cangahuala-Inocente et al. (2009) também sustentam que a embriogênese somática é um processo morfogenético com elevada alocação de energia, assim o catabolismo de amido resulta em compostos intermediário que fornecem o ATP necessário para o metabolismo celular. Este fato seria uma possível explicação para os baixos níveis de amido encontrados em CE no presente trabalho.

Além disso, Pescador et al. (2008) ainda mostram que, em culturas de $A$. sellowiana, células embriogênicas possuem grãos de amido menores e menos numerosos do que as células não-embriogênicas. Oropeza et al. (2001), assim como Ho, Vasil (1983), demonstram também que CE de cana-de-açúcar apresentam células pequenas, compactas e agregadas, com núcleos destacados e citoplasma denso, enquanto CNE apresentam células grandes, vacuolizadas e alongadas, com citoplasma escasso e com grânulos de amido. Esses autores afirmam que essas características celulares são o que tornam CE mais ativas metabolicamente e CNE menos ativas. 
Estudos apontaram que, em CE de diversas espécies como $A$. sellowiana (Cangahuala-Inocente et al., 2009), $P$. americana (Sánchez-Romero et al., 2002), $P$. mariana e P. glauca (Iraqi, Tremblay, 2001), o acúmulo de amido ocorreu especificamente em fases finais do desenvolvimento embrionário. Nesses trabalhos, como nas fases inicias do desenvolvimento há pouca quantidade de amido, possivelmente na multiplicação celular dessas culturas, momento que as células se tornaram competentes à embriogênese, células embriogênicas também possuíam conteúdo de amido baixo, como no presente trabalho.

Em M. arbórea os maiores níveis de amido também foram encontrados em CNE (Martin et al., 2000). Os autores observaram baixos níveis de amido e altos níveis de sacarose em CE, o que é coerente com dados analisados no presente estudo. Eles afirmam que diferenças de conteúdo de amido e açúcares solúveis são úteis como marcadores metabólicos entre CE e CNE.

\subsection{Proteínas}

Verificou-se pouca variação do conteúdo de proteínas totais em CE e diferenças não significativas no seu conteúdo em CNE, durante o experimento de multiplicação celular (figura 9). Entretanto, foi observado que o conteúdo de proteínas totais foi significativamente maior em CE, quando comparadas às CNE, em todos os momentos do cultivo celular (figura 9; tabela 1). Esses resultados são coerentes aos encontrados por Nieves et al. (2003), para a variedade CP-5243 de cana-de-açúcar e por Oropeza et al. (2001), para variedade cv. PR-62258. Blanc et al. (2002) afirmam ainda que o alto conteúdo de proteínas endógenas indica um metabolismo celular muito ativo e recém orientado (passando de células somáticas a células embrionárias).

Silveira et al. (2004b) afirmam que proteínas de reserva são fonte de aminoácidos para a germinação das sementes e são cruciais até que o embrião zigótico desenvolva o autotrofismo. Análogo ao desenvolvimento de embriogênese zigótica, em CE parece estar ocorrendo acúmulo de proteínas de reserva durante a multiplicação celular, que serão utilizadas como fonte de aminoácidos durante a maturação dos embriões somáticos. Segundo Silveira et al. (2004b) as principais 
substâncias de armazenamento acumuladas para formação de embriões são lipídios e proteínas.

Cangahuala-Inocente et al. (2009) sugeriram que altos níveis de proteína em embriões zigóticos utilizados como explantes, observados no momento da inoculação, podem ser considerados critério para a indução de embriogênese somática. Esse aumento protéico parece ser necessário para que o explante consiga responder à sinalização do meio de cultura e se torne competente à embriogênese somática, apontando assim maior conteúdo protéico em culturas competentes à desenvolver embriões. Esses autores afirmam ainda que podem haver proteínas que estão envolvidas na regulação da expansão celular e estabelecimento de características físicas necessárias para a morfogênese.

Oropeza et al. (2001) relacionam também o maior conteúdo protéico de CE a características citológicas de cada tipo de célula. CE possuem células com características que implicariam em alta atividade metabólica, com maiores níveis de proteínas, mRNAs, e outros componentes citoplasmáticos, enquanto as características de CNE implicariam em baixa atividade metabólica e baixos níveis protéicos. Esses autores demonstraram que diferenças entre CE e CNE se devem a um padrão protéico característico, encontrando proteínas de diferentes pesos moleculares para cada tipo celular (CE e CNE).

Em muitas espécies, como em O. catharinensis (Santa-Catarina et al., 2006), $P$. taeda (Silveira et al., 2004b) e A. sellowiana (Cangahuala-Inocente et al., 2009), foi observado um alto conteúdo protéico durante a maturação de embriões somáticos, e esse acúmulo é atribuído a produção de proteínas LEA, que são consideradas proteínas marcadores da embriogênese somática. Como as CE se mostram competentes e determinadas a produzir embriões, ao contrário das CNE, é explicita a existência de diferenças entre as culturas, e essas diferenças podem ser também atribuídas à produção de proteínas como as do tipo LEA, que geram então um maior conteúdo de proteínas totais em CE. Entretanto, esta hipótese somente poderá ser comprovada mediante a identificação destas proteínas.

Embora a base bioquímica e molecular da embriogênese somáticas tenha sido extensivamente estudada em cenoura (Daucus carota), padrões protéicos de CE e CNE dessa espécie são relativamente semelhantes. Ao contrário, as espécies de gramíneas têm um padrão mais complexo de proteínas relacionadas à 
embriogênese somática e esse padrão está relacionado ao efeito do 2,4-D utilizado para a indução de CE nessas espécies (Opereza et al., 2001). Dessa forma, mais estudos são necessários para determinar como a expressão diferencial de proteínas entre CE e CNE está relacionada à indução de competência da embriogênese somática em culturas de cana-de-açúcar.

\subsection{Poliaminas}

A análise de PAs permitiu estudar os conteúdos de Put, Spd, Spm, PAs totais e razão entre PAs. Put, spd e spm são as principais PAs encontradas nas plantas (Silveira et al., 2006; Santa-Catarina et al., 2007), sendo as PAs importantes moduladores de processos como crescimento, divisão e diferenciação celular e as detentoras de papeis importantes durante o desenvolvimento da embriogênese somática e zigótica. Portanto têm sido usadas como biomarcadores do desenvolvimento durante as diferentes fazes da embriogênese (Santa-Catarina et al., 2006). Adicionalmente, em coníferas, estudos indicam que as PAs estão envolvidas no estabelecimento da competência dos tecidos em responder à indução da embriogênese somática (Floh et al., 2007).

Na presente análise de PAs foi observado que Put está presente em maior quantidade nas CNE, quando comparadas às $C E$, durante todo o período de multiplicação celular (figura 10). Este padrão de acúmulo refletiu em uma média do conteúdo total de Put significativamente superior em CNE (tabela 1). Estes resultados estão de acordo com os obtidos na embriogênese somática de Quercus ilex (Mauri, Manzanera, 2011), sendo também encontrados maiores níveis de Put em tecidos que não geram embriões somáticos.

Já o conteúdo de Spd não apresenta grandes diferenças entre CE e CNE durante a multiplicação celular (figura 11). Porém a média do conteúdo total de Spd é maior em CE (tabela 1), como foi também observado por Mauri, Manzanera (2011), em Quercus ilex.

Adicionalmente, Spm apresentou maior média do conteúdo total em CNE, sendo a PA que se apresenta em menores valores em CE, assim como em CNE 
(tabela 1). Resultados similares para Spm foram encontrados na pesquisa de Silveira et al. (2004 b), para P. taeda.

Spd foi a PA que se apresentou com maiores concentrações em CE. Já em CNE a Put foi a PA com concentrações significativamente superiores (tabela 1). Durante o crescimento de CE em suspensão de $P$. taeda, altos níveis endógenos de Put foram associados com a redução do crescimento celular enquanto em $P$. sylvestris, a Spd parece retardar a proliferação celular e o crescimento, promovendo a maturação de embriões (Silveira et al., 2006).

Porém, dados encontrados no trabalho de Nieves et al. (2003), para a variedade CP-5243 de cana-de-açúcar, apesar de mostrarem o maior conteúdo de Spm em CNE e o maior conteúdo de Spd em CE, mostraram o conteúdo de Put mais elevado em CE, sendo esta PA predominante tanto em CE quanto em CNE, o que difere dos resultados encontrados no presente estudo. Nieves et al. (2003) também afirmam que os níveis elevados de Spd encontrados em CE de cana-deaçúcar podem ser correlacionados diretamente à embriogênese somática.

Já em culturas celulares de Nicotiana tabacum (Floh et al., 2007), embriões somáticos de O. catharinensis (Santa-Catarina et al., 2007) e CE de A. angustifolia (Silveira et al., 2006), também foi verificado que as PAs Spd e Spm reduzem o crescimento celular, promovem a evolução morfológica das CE concomitantemente a redução na síntese de óxido nítrico (NO). Put e o NO estariam relacionados com a divisão celular, enquanto a Spd e Spm estariam envolvidas na via de diferenciação e com a progressão da evolução morfogenética das CE (Silveira et al., 2006; Floh et al., 2007).

Floh et al. (2007) afirmam ainda que níveis elevados de Spd foram associadas às altas taxas de conversões de embriões somáticos. CE de $A$. angustifolia suplementadas com Spd e Spm no meio de cultura também reduziram o crescimento celular e geraram a evolução morfogenética de massas proembriogênicas (Silveira et al., 2006)

Em sistemas como $P$. abies (Santanen, Simola, 1992), $P$. radiata (Minocha et al., 1999), M. sativa (Cvikrová et al., 1999), e P. ginseng (Monteiro et al., 2002), aumentos significativos nos níveis de Spd também foram associados com a formação de embriões somáticos. Em diferentes sistemas vegetais tem sido 
sugerido que um adequado desenvolvimento embrionário está relacionado a uma diminuição dos níveis de Put, acompanhada por aumentos no conteúdo de Spd e Spm (Nieves et al., 2008).

Assim, tão importante quanto analisar o conteúdo de PAs em separado é analisar a razão entre PAs [Razão $P A s=P u t /(s p d+s p m)]$. Autores propõem que não apenas o conteúdo de PAs, mas também a relação Put/Spd, constitui importante biomarcador da capacidade regenerativa em plantas (Silveira et al., 2004a; SantaCatarina et al., 2006; Floh et al., 2007) .

No presente trabalho, em todos os momentos do experimento de multiplicação celular foram encontrados maiores valores de razão entre PAs em CNE (figura 14), decorrente da maior concentração de Put nestas culturas. Assim, a média do valor total da razão de PAs é significativamente menor em CE (tabela 1). Como pontuado por Nieves et al. (2008) para D. glomerata, a baixa razão entre PAs está relacionada à alta capacidade de desenvolver embriogênese. Uma reduzida razão entre PAs também foi relacionada com maior germinação de sementes e maior probabilidade de progressão na embriogênese somática (Silveira et al., 2004a; Santa-Catarina et al., 2006).

Os níveis mais elevados de Spd encontrados em CE estão em correspondência com uma baixa razão entre PAs encontrada nessas culturas, assim como os altos níveis de Put em CNE também se relacionam a alta razão entre PAs. Este padrão foi observado em estudos com diversas espécies, como em milho (Zea mays) e cana-de-açúcar (Nieves et al., 2003) e P. radiata (Minocha et al., 1999).

Em geral, os níveis de PAs são altos em tecidos que estão crescendo ativamente, sugerindo seu envolvimento na divisão celular e crescimento (SantaCatarina et al., 2007) e em tecidos que desenvolvem a embriogênese somática (Mauri, Manzanera, 2011). Contudo, a presente análise de PAs em cana-de-açúcar mostrou que as PAs totais estão em maiores concentrações em CNE, se comparadas às CE (tabela 1 ). Este resultado está coerente com o estudo de Nieves et al. (2003) com a mesma espécie. Nas CE as PAs totais não apresentam diferenças significativas durante o cultivo, enquanto em CNE apresentam pequenas variações de conteúdo durante a multiplicação celular (figura 13). 
Silveira et al. (2006) citam que a competência morfogenética em gimnospermas está associada a uma diminuição no conteúdo PAs livres enquanto em angiospermas esta característica está relacionada com altos níveis de PAs livres. Porém, os resultados obtidos sugerem que, em cana-de-açúcar, a competência morfogenética parece estar relacionada a um baixo nível de PAs livres totais.

Portanto, parecem ocorrer diferenças significativas nas concentrações de PAs em CE de diferentes espécies, indicando que o perfil destes compostos deve ser genótipo-dependente, como afirmado por Silveira et al. (2004b).

Os resultados obtidos neste trabalho indicam ainda diferentes perfis de PAs para CE e CNE, que são mais uma prova do papel crucial desempenhado pelas PAs na embriogênese somática de cana-de-açúcar, assim como de muitas outras espécies. 


\section{CONSIDERAÇÕES FINAIS}

Com os resultados obtidos em nosso trabalho foi possível analisar e comparar CE e CNE em seu crescimento celular, quantificando carboidratos solúveis (frutose, glicose e sacarose), amido, proteínas totais e PAs, determinando assim as alterações endógenas desses parâmetros durante o processo de multiplicação celular.

Com o acompanhamento do crescimento celular determinamos as curvas de crescimento de $\mathrm{CE}$ e CNE, efetuadas a partir de suas MF, demonstrando que as $\mathrm{CE}$ possuem maior crescimento celular comparativamente às CNE, o que parece se relacionar a uma maior atividade metabólica de CE. Além disso, se confirma que a escassez de nutrientes no meio de cultura influencia diretamente no crescimento celular in vitro. Foi observado ainda que as curvas de crescimento das culturas apontam semelhanças com o modelo de curva sigmóide apresentado por George (2008).

Com a quantificação de carboidratos durante a multiplicação celular, um menor conteúdo das hexoses analisadas foi encontrado em CE, o que parece se relacionar com uma reprogramação do metabolismo celular (Blanc et al., 2002). Em CE, a sacarose foi o carboidrato predominante, e a predominância deste carboidrato se relaciona ao alongamento celular e ao armazenamento de proteínas de reserva, para determinar a existência de potencial para desenvolver embriões somáticos. Além disso, foi possível determinar que em CE os metabolismos de glicose e frutose variam simultaneamente, mostrando estar diretamente ligados e serem utilizados nos mesmos momentos.

Porém o presente estudo não pôde explicitar se o carboidrato presente no meio de cultivo tem relações com os carboidratos intracelulares. Estudos posteriores, variando o tipo de carboidrato no meio e a quantidade destes carboidratos, com simultânea quantificação de carboidratos externos e internos durante todo desenvolvimento, se mostram de fundamental interesse para determinar se a presença de carboidratos no meio de cultivo realmente tem correlação com os carboidratos intracelulares. 
Com a análise de amido, verificou-se um maior conteúdo em CNE, o que também pode estar relacionado ao maior metabolismo das CE, que podem estar utilizando os carboidratos produzidos para desenvolvimento do ciclo celular, não formando reservas, o que confirma que o amido é rapidamente metabolizado em tecidos embrionários, fornecendo energia para as intensas atividades mitóticas.

Outra perspectiva de análise futura seria o estudo e quantificação das enzimas-chave relacionadas ao metabolismo de carboidratos, como realizado por Iraqi, Tremblay (2001) para o gênero Picea, para determinar se as diferenças no conteúdo de carboidratos e amido ocorrem por aumento de produção ou diminuição de consumo destas variáveis bioquímicas.

Com a quantificação protéica observamos que o conteúdo de proteínas totais é significativamente superior em CE, o que foi relacionado com a produção de proteínas específicas para o desenvolvimento do embrião. O aumento no conteúdo protéico foi relacionado, por diversos autores, a aquisição de competência para desenvolver embriões somáticos. Estudos futuros seriam necessários para determinar o padrão de proteínas encontrado na multiplicação de CE e CNE, o que pode ser realizado através de análises da expressão diferencial de proteínas utilizando ferramentas proteômicas.

Com a determinação de PAs, foi observado que Spd é a PA predominante em $\mathrm{CE}$, enquanto em CNE predomina a Put. Diversos autores relacionam maior teor de Spd com a capacidade de maturar embriões somáticos e com a evolução morfológica das CE. Já o maior conteúdo de Put está relacionado com a divisão celular e multiplicação, sem ocorrer a diferenciação. Esses dados estão coerentes com os encontrados para carboidratos e reforçam a capacidade de CE desenvolver embriões somáticos.

Também observamos uma razão entre PAs reduzida, bem como baixos níveis de PA totais, nas $C E$, o que tem sido relatado na literatura como determinante do adequado desenvolvimento embrionário. Para confirmar o papel das PAs durante o crescimento celular de CE e CNE e durante a maturação, diferentes PAs poderiam ser adicionadas ao meio de cultura, sendo seus conteúdos internos e externos determinados durante todo o desenvolvimento. Ainda, visando compreender os processos metabólicos de PAs durante a embriogênese somática de cana-deaçúcar, análises dos níveis de aminoácidos, principalmente daqueles envolvidos no 
metabolismo de PAs, como arginina, ornitina, metionina e citrulina, seriam de grande importância.

Em conjunto, os dados obtidos neste trabalho mostram que as CE e CNE de cana-de-açúcar possuem características bioquímicas diferentes, que possivelmente estão relacionadas com a modulação da sua competência embriogênica. 


\section{REFERÊNCIAS}

Asad S, Arshad M, Mansoor S, Zafar Y. Effect of various amino acids on shoot regeneration of sugarcane (Sacchrum officinarum L.). African Journal of Biotechnology; 2009;8;1214-1218.

Bais HP, Ravishankar GA. Role of polyamines in the ontogeny of plants and their biotechnological applications. Plant Cell, Tissue and Organ Culture; 2002;69:1-34.

Bewley JD, Black M. Seeds: physiology of development and germination. New York: Plenum Press; 1994;2;445.

Blanc G, Lardet L, Martin A, Jacob JL, Carron MP. Differential carbohydrate metabolism conducts morphogenesis in embryogenic callus of Hevea bradiliensis (Müll. Arg.). Journal of Experimental Botany; 2002;53;1453-1462.

Boudet J, Buitink J, Hoeskstra FA, Rogniaux H, Larre C, Satour P, Leprince O. Comparative analysis of the heat stable proteome of radicles of Medicago truncatula seeds during germination identifies late embryogenesis abundant proteins associated with desiccation tolerance. Plant Physiology; 2006;140;1418-1436.

Cangahuala-Inocente GC, Steiner N, Maldonado SB, Guerra MP. Patterns of protein and carbohydrate accumulation during somatic embryogenesis of Acca sellowiana. Brasília: Pesquisa Agropecuária Brasileira; 2009;44;217-224.

Cesnik R, Miocque J. Histórico. In: Cesnik R, Miocque J. Melhoramento da Cana-deaçúcar. Brasília: Empresa Brasileira de Pesquisa Agropecuária - Embrapa Meio Ambiente, Ministério da Agricultura, Pecuária e Abastecimento; 2004; Cap.1;23-30.

Chanprame S, Kuo TM, Widholm JM. Soluble carbohydrate content of soybean [Glycine max (L.) Merr.] somatic and zygotic embryos during development. In Vitro Cellular \& Developmental Biology Plant; 1998;34;64-68.

Chengalrayan K, Abouzid A, Gallo-Meagher M. In vitro regeneration of plants fron sugarcane seed-derived callus. In Vitro Cellular \& Developmental Biology - Plant; $2005 ; 41 ; 477-482$.

Cidade DAP, Garcia RO, Duarte AC, Sachetto-Martins G, Mansur E. Morfogênese in vitro de variedades brasileiras de cana-de-açúcar. Rio de Janeiro: Pesquisa Agropecuária Brasileira; 2006;41;385-391.

Companhia Nacional de Abastecimento. Acompanhamento da Safra Brasileira: Cana-de-Açúcar Safra 2011/2012. Terceiro levantamento. Brasília: Conab; Dezembro/2011. Disponível em: http://www.conab.gov.br/OlalaCMS/uploads/arquivos/11_12_08_11_00_54_08.pdf. Acessado em: 05 de Jan. de 2012.

De acordo com: International Committee of Medical Journal Editors. Uniform requirements for manuscripts submitted to Biomedical Journal: sample references. Available from: http://www.icmje.org [2007 May 22]. 
Cvikrová N, Binarová P, Cenklová V, Eder J, Machácková I. Reinitiation of cell division and polyamine and aromatic monoamine levels in alfafa explants during the induction of somatic embryogenesis. Physiologia Plantarum; 1999;105;330-336.

Delrot S, Atanassova R, Maurousset L. Regulation of sugar, amino acid and peptide plant membrane transporter. Biochimica et Biophysica Acta; 2000;1465;281-306.

Fehér A, Pasternak TP, Dudits D. Transition of somatic plant cells to an embryogenic state. Plant Cell, Tissue and Organ Culture; 2003;74;201-208.

Filson PB, Dawson-Andoh BE. Characterization of sugar from model and enzymemediated pulp hydrolyzates using high-performance liquid chromatography coupled to evaporative light scattering detection. Bioresource Technology; 2009;24;66616664.

Flinn BS, Roberts DR, Newton CH, Cyr DR, Webster FB, Taylor IEP. Storage protein gene expression in zygotic and somatic embryos of interior spruce. Physiology Plant; $1993 ; 89 ; 719-730$.

Floh EIS, Santa-Catarina C, Silveira V. Marcadores bioquímicos e moleculares para estudos da morfogênese in vitro. Revista Brasileira de Horticultura Ornamental; 2007;13;1992-2001.

Focks N, Benning C. Wrinkled1: a novel, low-seed-oil mutant of Arabidopsis with a deficiency in the seed-specific regulation of carbohydrate metabolism. Plant Physiology; 1998;118;91-101.

Gandonou C, Errabii T, Abrini J, Idaomar M, Chibi F, Senhaji NS. Effect of genotype on callus induction and plant regeneration from leaf explants of sugarcane (Saccharum sp.). African Journal of Biotechnology; 2005;4;1250-1255.

Geigenberger P, Stitt M, Fernie AR. Metabolic control analysis and regulation of the conversion of sucrose to starch in growing potato tubers. Plant Cell \& Environment; 2004;27;655-673.

George EF. Plant Tissue Culture Procedure - Background. In: George EF, Hall MA, De Klerk GJ. Plant Propagation by tissue culture. 3ed. Netherlands: Springer; 2008; Cap.1; Vol. 1;1-28.

Gibson SI. Control of plant development and gene expression by sugar signaling. Current Opinion in Plant Biology; 2005;8;93-102.

Gómez-González S, Ruiz-Jiménez J, Priego-Capote F, Castro MDL. Qualitative and quantitative sugar profiling in olive fruits, leaves, and stems by gas chromatography tandem mass spectrometry (GC-MS/MS) after ultrasound-assisted leaching. Journal of Agricultural and Food Chemistry; 2010;58;12292-12299. 
Grando MF, Franklin Cl, Shatters Jr. RG. Optimizing embryogenic callus production and plant regeneration fron 'Tifton 9' bahiagrass seed explants for genetic manipulation. Plant Cell, Tissue and Organ Culture; 2002;71;213-222.

Guerra MP, Torres AC, Teixeira JB. Embriogênese somática e sementes sintéticas. In: Torres AC, Caldas LS, Buso JA. Cultura de tecidos e transformação genética de plantas. Brasília: Embrapa; 1999; Cap. 3; Vol. 2;533-568.

Gutiérrez-Miceli FA, Rodríguez-Mendiola MA, Ochoa-Alejo N, Méndez-Salas R, Ariaas-Castro C, Dendooven L. Sucrose accumulation and enzyme activities in callus culture of sugarcane. Biologia Plantarum; 2005;49;475-479.

He Y, Young TE, Clark KR, Kleppinger-Sparace KF, Bridges WC, Sparace SA. Developmental profile of storage reserve accumulation in soybean somatic embryos. In Vitro Cellular \& Developmental Biology - Plant; 2011;47;725-733.

Ho WJ, Vasil IK. Somatic Embryogenesis in Sugarcane (Saccharum officinarum L): Growth and Plant Regeneration from Embryogenic Cell Suspension Cultures. Annals of Botany Company; 1983;51;719-726.

Hoenemann C, Richardt S, Kruger K, Zimmer AD, Hohe A, Rensing SA. Large impact of the apoplast on somatic embryogenesis in Cyclamen persicum offers possibilities for improved developmental control in vitro. Plant Biology; 2010;10;7793.

Iraqi D, Tremblay FM. Analysis of carbohydrate metabolism enzymes and cellular contents of sugar and proteins during spruce somatic embryogenesis suggests a regulatory role of exogenous sucrose in embryo development. Journal of Experimental Botany; 2001;52;2301-2311.

Krajñáková J, Häggman H, Gömöry D. Effect of sucrose concentration, polyethylene glycol and activated charcoal on maturation and regeneration of Abies cephalonica somatic embryos. Plant Cell, Tissue and Organ Culture; 2009;96;251-262.

Kennedy D, Norman C. What Don't we know? Science; 2005;309;5731:75.

Klimaszewska K, Morency F, Jones-Overton C, Cooke J. Accumulation pattern and identification of seed storage proteins in zygotic embryos of Pinus strobus and in somatic embryos from different maturation treatments. Physiologia Plantarum; $2004 ; 121 ; 682-690$.

Kormuták A, Vooková B. Biochemical variation between non-embryogenic and embryogenic calli of siver fir. Biology of Plants; 1997;39;125-130.

Kusano T, Berberich T, Tateda C, Takahashi Y. Polyamines: essential factors for growth and survival. Planta; 2008;228;367-381.

Lakshmanan P. Somatic embryogenesis in sugarcane. In Vitro Cellular \& Developmental Biology - Plant; 2006;42;201-205. 
Lakshmanan P, Geijskes RJ, Aitken KS, Grof CLP, Bonnett GD, Smith GR. Sugarcane biotechnology: the challenges and opportunities. In Vitro Cellular \& Developmental Biology - Plant; 2005;41;345-363.

Lelu-Walter MA, Bernier-Cardou M, Klimaszewska K. Clonal plant production from self- and cross-pollinated seed families of Pinus sylvestris (L.) through somatic embryogenesis. Plant Cell, Tissue and Organ Culture; 2008;92;31-45.

Lima MAC, Garcia RO, Sachetto-Martins G, Mansur E. Morfogênese in vitro e susceptibilidade de calos de variedades nacionais de cana-de-açúcar (Saccharum officinarum L.) a agentes seletivos utilizados em sistemas de transformação genética. Revista Brasileira de Botânica; 2001;24;73-77.

Lipavská H, Konrádová H. Invited review: Somatic embryogenesis in conifers: The role of carbohydrate metabolism. In Vitro Cellular \& Developmental Biology - Plant; 2004;40;23-30.

Marques D, Villari AC, Lerayer A. Guia da Cana-de-açúcar: Avanço científico beneficia o país. Brasil: Conselho de informações sobre biotecnologia; Set., 2009. Disponível em: http://www.cib.org.br/pdf/guia_cana.pdf, acessado em 28 de Nov. 2011.

Martin AB, Cuadrado Y, Guerra H, Gallego P, Hita O, Martin L, Dorado A, Villalobos $N$. Differences in the contents of total sugars, reducing sugars, starch and sucrose in embriogenic and non-embriogenic calli from Medicago arborea L. Plant Science; $2000 ; 154 ; 143-151$.

Martin KP, Beegum AS, Zhang CL, Slater A, Madhusoodanan PV. In vitro propagation of Ophirrhiza prostate through somatic embryogenesis. Biologia Plantarum; 2007;51;769-772.

Mauri PV, Manzanera JA. Somatic embryogenesis of holm oak (Quercus ilex L.): ethylene production and polyamine content. Acta physiologiae plantarum; $2011 ; 33 ; 717-723$.

McCormick AJ, Watt DA, Cramer MD. Supply and demand: sink regulation of sugar accumulation in sugarcane. Journal of Experimental Botany; 2009;60;357-364.

McCready RM, Guggolz J, Silveira V, Owens HS. Determination of starch and amylose in vegetables. Analytical Chemistry; 1950;22;1156-1158.

Merkle SA, Parrot WA, Flinn BS. Morphogenic aspects of somatic embryogenesis in plants. In: Thorpe TA. In vitro Embryogenesis in Plants. Dordrecht: Kluwer Academic Publishers; 1995; Cap. 5;155-203.

Minocha R, Dale RS, Cathie R, Steele KD, Minocha SC. Polyamine levels during the development of zygotic and somatic embryos of Pinus radiata. Physiologia Plantarum; 1999;105:155-164. 
Minocha R, Minocha SC, Long S. Polyamines and their biosynthetic enzymes during somatic embryo development in red spruce (Picea rubens Sarg.) In Vitro Cellular and Development Biology-Plant; 2004;40;572-580.

Monteiro M, Kevers C, Dommes J, Gaspar T. A specific role for spermidine in the initiation phase of somatic embryogenesis in Panax ginseng CA Meyer. Plant Cell, Tissue And Organ Culture; 2002;68;3;225-232.

Mordhorst AP, Toonen MAJ, De Vries SC. Plant Embryogenesis. Critical Reviews in Plant Sciences; 1997;16;535-576.

Mordocco AM, Brumbley JA, Lakshmanan P. Development of a temporary immersion system (RITA®) for mass production of sugarcane (Saccharum spp.). In Vitro Cell \& Developmental Biology - Plant; 2009;45;450-457.

Murashige T, Skoog F. A revised medium for rapid growth and bioassays with tobacco tissue cultures. Physiology Plant; 1962;15;473-497.

Natarajan S, Xu C, Caperna TJ, Garrett WM. Comparison of protein solubilization methods suitable for proteomic analysis of soybean seed proteins. Analytical Biochemistry; 2005;342;214-220.

Nieves N, Sagarra F, González R, Lezcano Y, Cid M, Blanco MA, Castillo R. Effect of exogenous arginine on sugarcane (Saccharum sp.) somatic embryogenesis, free polyamines and the contents of the soluble proteins and proline. Plant Cell, Tissue and Organ Culture; 2008;95;313-320.

Nieves N, Segura-Nieto M, Blanco MA, Sanchez M González A, González JL, Castillo R. Biochemical characterization of embryogenic and non-embryogenic calluses of sugarcane. In Vitro Cellular and Development Biology-Plant; 2003;39;343-345.

Opsahl S, Bennes R. Characterization of carbohydrates during early diagenesis of five vascular plant tissues. Organic Geochemistry; 1999;30;83-94.

Oropeza M, Marcano AK, De García E. Proteins related with embriogenic potential in callus and cell suspensions of sugarcane (Saccharum sp.). In Vitro Cellular and Development Biology-Plant; 2001;37;211-216.

Pescador R, Kerbauy GB, Kraus JE, Ferreira WM, Guerra MP, Figueiredo-Ribeiro RCL. Changes in soluble carbohydrates and starch amounts during somatic and zygotic embryogenesis of Acca sellowiana (Myrtaceae). In Vitro Cell; 2008;44;289299.

Pieruzzi FP, Dias LLC, Balbuena TS, Santa-Catarina C, Santos ALW, Floh EIS. Polyamines, IAA and ABA during germination in two recalcitrant seeds: Araucaria angustifolia (Gymnosperm) and Ocotea odorifera (Angiosperm). Annals of Botany; 2011;108;337-345. 
Pullman GS, Buchanan M. Identification and quantitative analysis of stage-specific carbohydrates in loblolly pine (Pinus taeda) zygotic embryo and female gametophyte tissues. Tree Physiology; 2008;28;985-996.

Rapaka VK, Faust JE, Dole JM, Runkle ES. Endogenous carbohydrate status affects postharvest ethylene sensitivity in relation to leaf senescence and adventitious root formation in Pelargonium cuttings. Postharvest Biology and Technology; $2008 ; 48 ; 272-282$.

Richard D, Lescot M, Inzé, D, De Veylder L. Effect of auxin, cytokinin, and sucrose on cell cycle gene expression in Arabdopsis thaliana cell suspension cultures. Plant Cell, Tissue and Organ Culture; 2002;69;167-176.

Rodgers KJ, Shiozawa N. Misincorporation of amino acid analogues into proteins by biosynthesis. The International Journal of Biochemistry \& Cell Biology; 2008;40;14521466.

Rodríguez GR, Costa JHP, Tomat DD, Pratta GR, Zorzoli R, Picardi LA. Pericarp total proteins profiles as molecular markes of tomato fruit quality traits in two segregation populations. Scientia Horticulturae; 2011;130;60-66.

Saare-Surminski K, Preil W, Knox JP, Lieberei R. Arabinogalactan proteins in embryogenic and non-embryogenic callus cultures of Euphorbia pulcherrima. Physiologia Plantarum; 2000;108;180-187.

Sánchez-Romero C, Perán-Quesada R, Barceló-Munoz A, Pliego-Alfaro F. Variations in storage protein and carbohydrate levels during development of avocado zygotic embryos. Plant Physiology and Biochemistry; 2002;40;1043-1049.

Santa-Catarina C, Silveira V, Balbuena TS, Viana AM, Estelita MEM, Handro W, Flow EIS. IAA, ABA, polyamines and free amino acids associated with zygotic embryo development of Ocotea catharinensis. Plant Growth Regulation; 2006;49;237-247.

Santa-Catarina C, Silveira V, Scherer GFE, Floh EIS. Polyamine and nitric oxide levels relate with morphogenetic evolution in somatic embryogenesis of Ocotea catharinensis. Plant Cell, Tissue and Organ Culture; 2007;90;91-101.

Santanen A, Simola LK. Changes in polyamine metabolism during somatic embryogenesis in Picea abies. Journal of Plant Physiology; 1992;140:475-480.

Santiago AD, Ivo WMPM, Barbosa GVS, Rosseto R. Impulsionando a Produtividade e a Produção Agrícola da Cana-de-Açúcar no Brasil. In: Workshop Internacional sobre Desenvolvimento da Agricultura Tropical. Transformando a Agricultura Tropical: Uma avaliação das Principais Inovações Tecnológicas, Institucionais e Políticas. Brasília; 2006; p.1-4.

Santos ALW, Silveira V, Steiner N, Maraschin M, Guerra MP. Biochemical and Morphological Changes during the Growth netics of Araucaria angustifolia 
Suspension Cultures. Brazilian Archives of Biology and Technology; 2010;53;497504.

Sghaier B, Bahloul M, Bouzid RG, Drira N. Development of zygotic and somatic embryos of Phoenix dactylifera L. cv. Deglet Nour: Comparative study. Scientia Horticulturae; 2008;116;169-175.

Sghaier-Hammami B, Drira N, Jorrín-Novo JV. Comparative 2-DE proteomic analysis of date palm (Phoenix dactylifera L.) somatic and zygotic embryos. Journal of Proteomics;2009; 73;161-177.

Silveira V, Balbuena TS, Santa-Catarina C, Floh EIS, Guerra MP, Handro W. Biochemical changes during zygotic embryogenesis in Pinus taeda L. Plant Growth Regulation;2004b; 44;147-156.

Silveira V, Floh EIS, Handro W, Guerra MP. Effect of plant growth regulators on the cellular growth and levels of intracellular protein, starch and polyamines en embryogenic suspension cultures of Pinus taeda. Plant Cell, Tissue and Organ Culture; 2004a;76;53-60.

Silveira V, Santa-Catarina C, Tun NN, Scherer GFE, Handro W, Floh EIS. Polyaminies effects on the endogenous polyamines contents, nitric oxide release growth and differentiation of embryogenic suspension cultures of Araucaria angustifolia (Bert.) O. Ktze. Plant Science; 2006;171;91-98.

Silveira V, Steiner N, Santos ALW, Nodari RO, Guerra MP. Biotechnology tolls in Araucaria angustifolia conservation and improvement: inductive factors affecting somatic embryogenesis. Crop Breeding and Applied Biotechnology; 2002;2;463-470.

Smeekens S. Sugar-induced signal transduction in plants. Annual Review Plant Physiology and Plant Molecular Biology; 2000;51;49-81.

Snyman SJ, Meyer GM, Koch AC, Banasiak M, Watt MP. Applications of in vitro culture systems for commercial sugarcane production and improvement. In Vitro Cellular \& Developmental Biology - Plant; 2011;47;234-249.

Steiner N, Santa-Catarina C, Andrade JBR, Balbuena TS, Guerra MP, Handro W, Floh EIS, Silveira V. Review: Araucaria angustifolia Biotechnology. Functional Plant Science and Biotechnology; 2008;2;20-28.

Steiner N, Santa-Catarina C, Silveira V, Floh EIS, Guerra MP. Polyamines effects on growth and endogenous hormones levels in Araucaria angustifolia embryogenic cultures. Plant Cell, Tissue Organs and Cultures; 2007;89;55-62.

Tautorus TE, Fowke LC, Dunstan DI. Somatic embryogenesis in conifers. Canadian Journal of Botany; 1991;69;1873-1899.

Veiga CFM, Vieira JR, Morgado IF. Diagnóstico da cadeia produtiva de cana-deaçúcar do Estado do Rio de Janeiro: relatórios de pesquisa. Rio de janeiro: FAPERJ, 
SEBRAE-RJ; 2006; $\quad$ Cap.1;15-34. Disponível em http://sistemafaerj.com.br/images/biblioteca/cana_vfinal.pdf. Acessado em: 28 de Nov. de 2011.

Vettore AL, Silva FR, Kemper EL, Souza GM, Silva AM. Analysis and functional annotation of an expressed sequence tag collection for tropical crop sugarcane. Genome Research; 2003;13;2725-2735.

Vogel G. How Does a Single Somatic Cell Become A Whole Plant? Sci.; $2005 ; 309 ; 86$.

Wallace HM, Fraser AV, Hughes A. A perspective of polyamine metabolism. Biochemical Journal; 2003;376;1-14. 